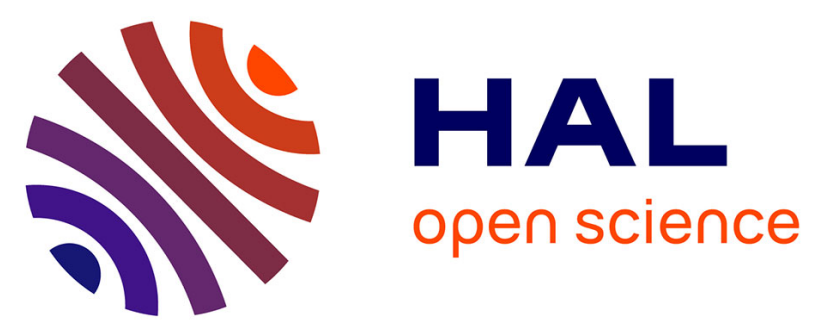

\title{
Volcanic Markers of the Post-Subduction Evolution of Baja California and Sonora, Mexico: Slab Tearing Versus Lithospheric Rupture of the Gulf of California
} Thierry Calmus, Carlos Pallares, René Maury, Alfredo Aguillón-Robles, Hervé Bellon, Mathieu Benoit, François Michaud

\section{To cite this version:}

Thierry Calmus, Carlos Pallares, René Maury, Alfredo Aguillón-Robles, Hervé Bellon, et al.. Volcanic Markers of the Post-Subduction Evolution of Baja California and Sonora, Mexico: Slab Tearing Versus Lithospheric Rupture of the Gulf of California. Pure and Applied Geophysics, 2011, 168 (8-9), pp.13031330. 10.1007/s00024-010-0204-z . insu-00543676

\section{HAL Id: insu-00543676 \\ https://hal-insu.archives-ouvertes.fr/insu-00543676}

Submitted on 25 Feb 2011

HAL is a multi-disciplinary open access archive for the deposit and dissemination of scientific research documents, whether they are published or not. The documents may come from teaching and research institutions in France or abroad, or from public or private research centers.
L'archive ouverte pluridisciplinaire HAL, est destinée au dépôt et à la diffusion de documents scientifiques de niveau recherche, publiés ou non, émanant des établissements d'enseignement et de recherche français ou étrangers, des laboratoires publics ou privés. 


\section{Volcanic markers of the post-subduction evolution of Baja \\ California and Sonora, Mexico: Slab tearing versus lithospheric rupture of the Gulf of California}

Thierry Calmus ${ }^{\mathrm{a}, *}$, Carlos Pallares ${ }^{\mathrm{a}, \mathrm{b}}$, René C. Maury ${ }^{\mathrm{b}}$, Alfredo Aguillón-Robles ${ }^{\mathrm{c}}$, Hervé Bellon $^{\mathrm{b}}$, Mathieu Benoit ${ }^{\mathrm{d}}$, François Michaud ${ }^{\mathrm{e}}$

a Estación Regional del Noroeste, Instituto de Geología, Universidad Nacional Autónoma de México, Hermosillo, Son., C.P. 83000, México

b Université Européenne de Bretagne, Université de Brest; CNRS; UMR 6538 Domaines Océaniques; Institut Universitaire Européen de la Mer, Place N. Copernic, 29280 Plouzané, France.

c Instituto de Geología, UASLP, Av. Dr. Manuel Nava no. 5, Zona Universitaria, San Luis Potosí, S.L.P., C.P. 78250, México.

d UMR 5562, OMP, Université Paul Sabatier, 14 Avenue Edouard Belin, F-31400 Toulouse, France

e UMR 6526, Géosciences Azur, Université Pierre et Marie Curie, F-06235 Villefranche sur Mer, France.

* Corresponding author: e-mail: tcalmus@ servidor.unam.mx 


\section{Abstract}

The study of the geochemical compositions and K-Ar or Ar-Ar ages of ca. 350 Neogene and Quaternary lavas from Baja California, the Gulf of California and Sonora allows us to discuss the nature of their mantle or crustal sources, the conditions of their melting and the tectonic regime prevailing during their genesis and emplacement. Nine petrographic/geochemical groups are distinguished: "regular" calc-alkaline lavas; adakites; magnesian andesites and related basalts and basaltic andesites; niobium-enriched basalts; alkali basalts and trachybasalts; oceanic (MORB-type) basalts; tholeiitic/transitional basalts and basaltic andesites; peralkaline rhyolites (comendites); and icelandites. We show that the spatial and temporal distribution of these lava types provides constraints on their sources and the geodynamic setting controlling their partial melting. Three successive stages are distinguished.

Between 23 and $13 \mathrm{Ma}$, calc-alkaline lavas linked to the subduction of the PacificFarallon plate formed the Comondú and central coast of Sonora volcanic arc. In the extensional domain of western Sonora, lithospheric mantle-derived tholeiitic to transitional basalts and basaltic andesites were emplaced within the southern extension of the Basin and Range province.

The end of the Farallon subduction was marked by the emplacement of much more complex Middle to Late Miocene volcanic associations, between 13 and 7 Ma. Calc-alkaline activity became sporadic, and was replaced by unusual post-subduction magma types including adakites, niobium-enriched basalts, magnesian andesites, comendites and icelandites. The spatial and temporal distribution of these lavas is consistent with the development of a slab tear, evolving into a $200 \mathrm{~km}$-wide slab window sub-parallel to the trench, and extending from the Pacific coast of Baja California to coastal Sonora. Tholeiitic, transitional and alkali basalts of subslab origin ascended through this window, adakites derived from the partial melting of its upper lip, relatively close to the trench, and calc-alkaline lavas, magnesian andesites and niobium-enriched basalts formed from hydrous melting of the supraslab mantle triggered by the uprise of hot Pacific asthenosphere through the window.

During the Plio-Quaternary, the "no-slab" regime following the sinking of the old part of the Farallon plate within the deep mantle allowed the emplacement of alkali and tholeiitic/transitional basalts of deep asthenospheric origin in Baja California and Sonora. The lithospheric rupture connected with the opening of the Gulf of California generated a high thermal regime associated to asthenospheric uprise, and emplaced Quaternary depleted MORBtype tholeiites. This thermal regime also induced partial melting of the thinned lithospheric 
mantle of the Gulf area, generating calc-alkaline lavas as well as adakites derived from slivers of oceanic crust incorporated within this mantle.

\begin{abstract}
Keywords: slab tearing, slab melting, ridge-trench collision, adakite, basalt, comendite, magnesian andesite, asthenospheric window, Basin and Range, Gulf of California, Baja California, Sonora, México
\end{abstract}

\title{
1. Introduction
}

The geochemical (major, trace elements and isotopic) compositions of fresh magmatic rocks are mostly inherited from those of their source materials during partial melting, although they may have been modified later by intracrustal petrogenetic processes such as fractional crystallization coupled or not with assimilation of host rocks, or magma mixing. On one hand, experimental studies allow the petrologist to take into account the geochemical effects linked to variable source mineralogy, temperature, pressure, and melting rate on the composition of the melts. On the other hand, the presence of a given source at depth and the physical conditions governing its partial melting are controlled by the regional geodynamic setting. Magmatic rocks are thus potential markers of the tectonic regime prevailing during their emplacement.

The Neogene and Quaternary geological history of Baja California, Sonora and Gulf of California has been marked by the almost continuous emplacement of volcanic rocks showing an exceptional geochemical diversity (Gastil et al., 1979; Sawlan, 1991; Benoit et al., 2002). Mafic lavas encompass the whole range of basaltic compositions, from depleted mid-oceanic ridge basalts (MORB) to plume-type alkali basalts, through various kinds of tholeiitic, transitional and calc-alkaline basalts and the very rare niobium-enriched basalts (NEB: Aguillón-Robles et al., 2001). Intermediate and evolved lavas are also highly diversified. In addition to the types commonly found in calc-alkaline series, they include unusual rocks such as magnesian andesites (Saunders et al., 1987; Calmus et al., 2003), adakites (Aguillón-Robles et al., 2001; Calmus et al., 2008), icelandites and peralkaline rhyolites (Vidal-Solano et al., 2008a, b). 
A majority of authors have considered this geochemical diversity as resulting from the partial melting of contrasted mantle and crustal sources, during the complex tectonic evolution of the Pacific margin, which followed the end of the subduction of the Farallon oceanic plate around 12.5 Ma. In Baja California, the wide range of erupted magmas is generally attributed to the opening of an asthenospheric window, although the details of the process are debated: for instance, the source of adakites is thought to be either the subducted Farallon crust or the mafic base of the continental crust (see Pallares et al., 2007, 2008; Castillo, 2008, 2009; Maury et al., 2009, and references therein). In Sonora, the association of tholeiitic to transitional basalts (temporally evolving towards alkali basalts) with icelandites and peralkaline rhyolites is linked to the transition from a typical Basin and Range regime to rift opening in the nearby Gulf of California (Vidal-Solano et al., 2008a, b).

However, a rather different point of view has been developed in two recent articles. Negrete-Aranda and Cañón-Tapia (2008) consider that a stalled Farallon slab is still present beneath Baja California, and that the post-subduction magmas originated from sources located in the mantle wedge or the overlying continental crust. These authors claim that the partial melting of these sources was due to the thermal rebound following the end of subduction, and that the temporal and spatial distribution of post-subduction lavas resulted from local tectonic features like the stress field and the tensile strength of the Baja California crustal rocks. Till et al. (2009) consider all the Miocene volcanism in Sonora as subduction-related (continental arc type), and find only subtle geochemical changes (slight variations of incompatible element ratios, e.g. La/ $\mathrm{Nb}$ ) concomitant with the ridge-trench collision off Baja California at $12.5 \mathrm{Ma}$. They suggest that the subduction signature of the sub-arc Sonoran mantle was not erased 4 m.y. after the end of subduction, and thus that what they call "petrotectonic modeling" is a perilous exercise.

Numerous good quality geochemical analyses of K-Ar and/or Ar-Ar dated lavas from Baja California Peninsula, the Gulf of California islands and coastal Sonora have been published during the last ten years. The purpose of this paper is to review them, to discuss their implications on the nature of the magmatic sources at depth, and finally to examine critically the constraints that they may provide on the tectonic evolution of the Pacific margin of northwestern México.

\section{Tectonic framework}


The Middle Miocene to Recent tectonic and magmatic evolution of northwestern

Mexico is closely related to the transition between subduction regime and the opening of the Gulf of California. After the Pacific-Farallon ridge entered the trench at the latitude of presentday Los Angeles, the Rivera triple junction migrated progressively to the south, until the eastwards subduction of Farallon plate and subsequent microplates below North America plate ended between 12.5 and $12.3 \mathrm{Ma}$ with the capture of microplates by the Pacific plate (Lonsdale, 1991). This is the case north of the Shirley transform fault, when the sea-floor spreading between Pacific and Farallon plates stooped after Chron 5AB (Lonsdale, 1991) and more precisely during the younger part of the Chron 5A (Dyment, 2003) along the Guadalupe ridge. South of the Shirley transform fault, this capture was progressive until 8 to $7 \mathrm{Ma}$, period during which the Pacific-Magdalena ridge experienced a break into several segments, together with $\mathrm{a} \sim 50^{\circ}$ clockwise rotation (Michaud et al., 2006). After that rotation, the direction of demising seafloor spreading along the ridge segments was closely parallel to the margin, which suggests (1) that the spreading centers segments accommodated the main part of the transcurrent motion between Pacific and North America plates before 8-7 Ma (Michaud et al., 2006), and (2) that the onset of the activity of the San Benito-Tosco Abreojos fault zone (Spencer and Normark, 1989) probably occurred at that time.

The limit between Pacific and North America plates was located along the ToscoAbreojos and San Benito fault zones from 8-7 Ma until ca. $6 \mathrm{Ma}$, when the transtensional regime in the Gulf of California became established. The displacement along the ToscoAbreojos-San Benito fault system is evaluated to 350 to $400 \mathrm{~km}$, which is the offset necessary to complete the $650-700 \mathrm{~km}$ of the northwest relative motion of Pacific plate with respect to North America since 12.3 Ma (Atwater and Stock, 1998), after restoring the offset of $276 \mathrm{~km}$ accumulated within the Gulf of California since 6.3 Ma (Oskin and Stock, 2003). Based on the provenance data of detrital zircons, Fletcher et al. (2007) concluded that the dextral slip along the Tosco-Abreojos fault was less that $150 \mathrm{~km}$, and that the main transform boundary between Pacific and North America plates was the Gulf of California, between 12.5 and $6 \mathrm{Ma}$. In both cases, west of the Main Gulf Escarpement (MGE), Baja California Peninsula is considered to be stable between Upper Miocene and Present. No major fault is known between ToscoAbreojos fault and the MGE. East verging normal faults of the western Los Cabos block belong to the rifting structures of the Gulf Extensional Province (GEP). Minor faults are associated with some volcanic fields of Baja California Sur such as La Purisima (Bellon et al., 
2006). The adakitic domes and dykes of Santa Clara volcanic field are aligned along a NW-SE direction, subparallel to the paleotrench off Vizcaino Peninsula.

On the continent, prior to the opening of the Gulf of California, we can distinguish two morpho-tectonic regions that were inherited from the Paleogene and Early Miocene geologic evolution, marked by the subduction of the Farallon plate: (1) To the east, a large Basin and Range province which is part of the Southern Basin and Range province (Sonder and Jones, 1999). It is divided into three NNW-SSE trending areas (e.g. Henry, 1989); an eastern Basin and Range subprovince that extends from the Rio Grande Rift to the Trans-Mexican Volcanic Belt; a western Basin and Range province extending between the western limit of the Sierra Madre Occidental (SMO) and the Main Gulf Escarpment (MGE); and finally the Sierra Madre Occidental, a huge Oligocene volcanic belt, corresponding to a relatively unextended domain located between the western and eastern Basin and Range subprovinces, respectively. (2) West of the MGE, the Peninsular Ranges belt which backbone is composed mainly by plutons of the Cretaceous magmatic arc, together with some accreted terranes along the western margin. This zone is not affected by Basin and Range extension. Based on the previous morphotectonic distinction, we conclude that the MGE coincides with the western limit of the Basin and Range province. Henry (1989, his Fig. 7) reported that the region surrounding the Gulf of California experienced intense faulting during Basin and Range extension, before the opening of the Gulf of California. He also considered that normal faults aligned with the MGE represent the western limit of the Basin and Range Province.

A majority of authors agree to consider that NE-SW extension observed along and east of the MGE is related the opening of the Gulf of California (e.g. Stock and Hodges, 1989). Nevertheless, in the southern Sierra Juarez, along the present eastern coast of Baja California, Lee et al. (1996) interpreted west-dipping normal faulting which occurred between $15.98 \pm$ 0.13 and $10.96 \pm 0.05 \mathrm{Ma}$ as the first east-west extension of the Gulf Extensional Province (GEP). That age is coeval with some ages of Basin and Range extension determined in Sonora, and it is thus necessary to distinguish the extension related to Basin and Range from the extension due to lithosphere breakup at the beginning of the opening of the Gulf of California. That distinction has been also questionned by Dokka and Merriam (1982) for the region of Puertecitos, and Stock and Hodges (1989) for the whole Gulf region. These last authors propose that the eastern limit of the GEP coincides with the western limit of the SMO, but recognize at the same time that the limit of the GEP is not well defined in Sonora, due to the lack of reliable data. In the work of Stock and Hodges (1989) as well as in many others papers, 
the use of the acronym GEP is accompanied by a reference to the classical study of the geology of the state of Baja California, Mexico, by Gastil et al. (1975). Nevertheless, a detailed lecture of that exhaustive work does not show any evidence for a precise description of such a morphologic or tectonic province. Gastil et al. (1975) present the Gulf of California depression (p. 76 and 131) as a structural province limited by the coast of Sonora and the MGE in Baja California, probably reported for the first time by Gabb (1882) as "an enormous fault" along the coastline between La Paz and Mulege. Later maps of the GEP (Lee et al., 1996; Till et al., 2009 and many others), refer to the figure 1 of Gastil et al. (1975) where the authors presented the Basin and Range province (and not a hypothetical GEP) as extending in northwestern Mexico from the Sierra Madre Occidental western escarpment to the east to the MGE to the west. Henry and Aranda Gómez (2000) presented a new evaluation of the 12-6 Ma extension around the Gulf of California, and concluded that it occurred probably throughout the southern Basin and Range province, including the eastern Basin and Range, east of the SMO. In the case of Sonora, they reported tilted volcanic rocks younger than 12-10 Ma but the highest angles of dip were observed in Sierra Santa Ursula, close to the Gulf of California. Following RoldánQuintana et al. (2004) and Calmus et al. (1997), we will consider that the eastern limit of the GEP in Sonora might correspond to the Empalme graben and its continuation toward the north along the Hermosillo graben. To the east of that limit, minor tilting and extension could be associated to Late Miocene waning Basin and Range extension within a Miocene Extensional Arc Province as suggested by Gans (1997).

\section{Lava types: their occurrences, specific geochemical features and mantle/crustal sources}

\subsection{Data base and classification}

We have compiled ca. 350 chemical analyses of ${ }^{40} \mathrm{~K}-{ }^{40} \mathrm{Ar}$ or ${ }^{40} \mathrm{Ar}-{ }^{39} \mathrm{Ar}$ dated Neogene and Quaternary lavas for which a large set of major and trace element data, mostly obtained by Inductively Coupled Plasma-Atomic Emission Spectrometry (ICP-AES) and Inductively Coupled Plasma-Mass Spectrometry (ICP-MS), is available. Our main source of data for Baja California is a set of papers (Aguillón-Robles et al., 2001; Benoit et al., 2002; Calmus et al., 2003; Bellon et al., 2006; Pallares et al., 2007, 2008; Calmus et al., 2008) for which the 
analytical techniques are described by Cotten et al. (1995). For coastal Sonora, we have mostly used the set of data of Vidal-Solano et al. (2005, 2008a,b) and Till et al. (2009).

Calc-alkaline lavas showing a typical subduction-related geochemical signatures have been classified according to their $\mathrm{K}_{2} \mathrm{O}$ and $\mathrm{SiO}_{2}$ contents (Peccerillo and Taylor, 1976), and other lavas according to the TAS diagram (Le Bas et al., 1986). Transitional basalts are defined according to Middlemost's (1975) criteria, and adakites according to the Sr/Y versus Y plot of Defant and Drummond (1990). Niobium-enriched basalts (NEB) are named after their original description in Santa Clara volcanic field, Baja California (Aguillón-Robles et al., 2001), although their definition and relationships with alkali basalts are still a matter of debate (Castillo, 2008, 2009; Maury et al., 2009).

\section{2. "Regular" calc-alkaline lavas}

Calc-alkaline lavas form the bulk of the Comondú Late Oligocene to Middle Miocene calc-alkaline belt (Gastil et al., 1979; Hausback, 1984; Umhoefer et al., 2001). It extends all along the eastern part of the Baja California Peninsula from $32^{\circ} \mathrm{N}$ to $24^{\circ} \mathrm{N}$ (Fig. 1), mostly as coalescent stratovolcanoes along its main ridge, and also forms the bulk of volcanic cover of Isla Tiburón and a number of sierras close to the coast of central Sonora. Medium-K to high-K andesites are prominent, with subordinate dacites, basaltic andesites and basalts. These lavas are highly porphyritic, with pheocrysts of plagioclase (labradorite), clinopyroxene (augite, diopside) and olivine altered to iddingsite, together with occasional crystals of hornblende, titanomagnetite and orthopyroxene. They display a characteristic "subduction-related" incompatible element signature, with high ratios of Large Ion Lithophile Elements (LILE) such as $\mathrm{Ba}$ and $\mathrm{Sr}$ over High Field Strength Elements (HFSE) and typical depletion of the latter, resulting in negative $\mathrm{Nb}$ and $\mathrm{Ti}$ anomalies in their multi-element patterns (Fig. 2a). The fractionated character of their rare earth element (REE) patterns is mostly due to their high contents in light REE (LREE; e.g. La, Ce). Unlike adakites and related rocks, they are not selectively depleted in yttrium and heavy REE (HREE) and therefore display low $\mathrm{Sr} / \mathrm{Y}(<20)$ and $\mathrm{La} / \mathrm{Yb}(<10)$ ratios. In the following discussion they will be referred to as "regular" calcalkaline lavas (opposed to adakites and related rocks).

The Comondú volcanic belt was active until 15-14.5 Ma in northern Baja California (Martín et al., 2000; Pallares et al., 2007; Fig. 3a); until 11 Ma in Baja California Sur (Sawlan and Smith, 1984; Sawlan, 1991; Bellon et al., 2006); and until 12-11 Ma in Sonora (Mora- 
Klepeis and McDowell, 2004; Vidal-Solano et al., 2008a; Till et al., 2009). However, limited California and Sonora (Fig. 3b), until 5.8 Ma in Puertecitos (Martín-Barajas et al., 1995), 7.3 Ma in Jaraguay (Pallares et al., 2007) and 8.3 Ma in Sierra El Aguaje (Till et al., 2009). Then, it resumed during the Plio-Quaternary along the eastern coast of Baja California and within the Gulf of California (Figs. 1 and 3c), emplacing several volcanic edifices, most of them of medium-K composition. These include from north to south: the youngest lavas of the Puertecitos volcanic field (3.2-2.7 Ma; Martín-Barajas et al., 1995), Isla San Luis (Pleistocene; Paz-Moreno and Demant, 1999), the Cerro Starship centre in the SW of Isla Tiburón (5.7-3.7 Ma; Oskin and Stock, 2003), Isla San Esteban (4.5-2.5 Ma; Desonie, 1992; Calmus et al., 2008), Tres Virgenes young volcano (160-36 ka; Schmitt et al., 2006), La Reforma and El Aguajito calderas (1.4-1.2 Ma; Demant, 1984; Garduño-Monroy et al., 1993; Schmitt et al., 2006), Cerro Los Mencenares volcanic centre (4.3-3.8 Ma; Bigioggero et al., 1995; AguillónRobles, 2002), and Isla Coronado (0.69 Ma-Holocene; Bigioggero et al., 1987). Some of these volcanic edifices contain, in addition to "regular" calc-alkaline lavas, adakites (Isla San Esteban; Calmus et al., 2008) or lavas plotting within the adakite field in most geochemical diagrams (Isla Coronado, Cerro Mencenares, Tres Virgenes; see below).

Although no specific geochemical modelling of the origin of the Comondú "regular" calc-alkaline lavas has been attempted, all authors have assumed that these andesite-dominated suites derive from the usual arc lava source, i.e. the supraslab mantle metasomatized by hydrous fluids transferred from the downgoing Pacific-Farallon plate (Arculus, 1994; Stern, 2002). The origin of calc-alkaline lavas younger than the postulated end of the subduction event (ca. 12.5 Ma) has also been attributed to the delayed partial melting of this previously metasomatized source (Bellon et al., 2006; Till et al. 2009). This melting may have been triggered by the heat supply from the Pacific asthenosphere during the Late Miocene development of an asthenospheric window (Pallares et al., 2007, 2008), and later by the high thermal regime linked to the opening of the Gulf of California (Calmus et al., 2008).

\subsection{Adakites and lavas intermediate between adakites and calc-alkaline lavas}

Adakites (Defant and Drummond, 1990) or high-silica adakites (Martin et al., 2005) are low-K to medium-K andesitic and dacitic rocks $\left(\mathrm{SiO}_{2}=56-70\right.$ wt.\%), usually amphibole-rich, the geochemical signature of which shows the high LILE/HFSE ratios and relative depletion in 
$\mathrm{Nb}$ typical of calc-alkaline magmas (Fig. 2b). In addition, they display highly fractionated REE (> 50) and equivalent ratios, and isotopic $\mathrm{Sr}, \mathrm{Nd}, \mathrm{Pb}$ signatures similar to that of oceanic MORB-type basalts. Their characteristic Y and HREE depletion (Fig. 2b) is thought to traduce the selective incorporation of these elements in garnet (either residual garnet in their source or deep fractionation of garnet from the early melts). Adakites are generally considered as derived either (i) from the partial melting of subducted oceanic crust metamorphosed into the garnet amphibolite or eclogite facies (Defant and Drummond, 1990; Sen and Dunn, 1994a; Martin, 1999; Defant and Kepezhinskas, 2001; Martin et al., 2005), or (ii) from the partial melting of the mafic base of thickened Andean-type crust (Atherton and Petford, 1993; Petford and Atherton, 1996; Arculus et al., 1999), or finally from (iii) high-pressure fractionation (involving separation of garnet) of basaltic to andesitic liquids in mantle conditions (Prouteau and Scaillet, 2003; Müntener and Ulmer, 2006; Alonso-Perez et al., 2009). In addition to typical adakites, the compositions of which match those of experimental garnet amphibolite or garnet eclogite partial melts, many adakite associations contain rocks displaying $\mathrm{Sr} / \mathrm{Y}$ and $\mathrm{La} / \mathrm{Yb}$ ratios intermediate between the former and calc-alkaline melts. These rocks might result either from mixing involving the two kinds of melts (Jego et al., 2005), or alternatively from variable fractionation of garnet or garnet + amphibole in calc-alkaline magmas (e.g. Macpherson et al., 2006; Chiaradia et al., 2009).

Adakites have never been identified in Sonora, but several occurrences are described (and other suspected) in Baja California and the Gulf of California islands. The largest is the Late Miocene Santa Clara volcanic field (Vizcaino Peninsula), the volume of which is estimated to $25 \mathrm{~km}^{3}$. In this area, ca. 20 dacitic domes and up to $250 \mathrm{~m}$ thick associated lava flow and pyroclastic flow sequences were emplaced between 11 and 8.7 Ma (Aguillón-Robles et al., 2001; Benoit et al., 2002), in close spatial and temporal association with niobiumenriched basalts (NEB). In addition, adakites dated between 6.2 and 4.9 Ma have been reported by Bonini and Baldwin (1998) from Isla Santa Margarita, and an adakitic dyke 9.7 Ma old from the Jaraguay volcanic field (Pallares et al., 2007). In the Santa Rosalía basin, adakitic flows (the Santa Rosalía dacites) were emplaced between 12.5 and 12.3 Ma (Conly et al., 2005).

Pliocene (4.5-2.6 Ma old) adakitic andesites and dacites, associated with contemporaneous calc-alkaline lavas, have been reported from Isla San Esteban in the Gulf of California (Calmus et al., 2008). Although they were not identified as such by former authors, Pliocene-Quaternary adakites or adakite-related lavas might also occur in several other 
volcanic centres. Indeed, analyses of dacites or andesites displaying low heavy rare earth elements (HREE) and $\mathrm{Y}$ contents together with high $\mathrm{Sr} / \mathrm{Y}$ and $\mathrm{La} / \mathrm{Yb}$ ratios have been recorded from the Pliocene Cerro Mencenares complex (Bigioggero et al., 1995), and the Quaternary Isla Coronado (Bigioggero et al., 1987) and Tres Virgenes volcanoes (Cameron and Cameron, 1985).

The origin of Late Miocene Baja California adakites has been attributed to the melting of the subducting Pacific-Farallon oceanic crust along the edges of an asthenospheric window (Aguillón-Robles et al., 2001; Benoit et al., 2002; Pallares et al., 2007). This interpretation has been challenged by Castillo (2008) who prefers that of the partial melting of metabasites from the base of the Baja crust. However, the thickness of this crust (less than $33 \mathrm{~km}$ ) may not allow garnet to be stable in such conditions (Maury et al., 2009). In addition, the occurrence of mantle-derived ultramafic xenocrysts and xenoliths in Rancho San Lucas adakite (Santa Clara) suggests that adakitic melts ascended through the upper Baja mantle, and thus derived either from the downgoing slab (Maury et al., 2009) or alternatively from delaminated Baja crust slivers (Castillo, 2009). The source of the Pliocene San Esteban adakites, which overlie a still thinner continental crust and clearly post-date the subduction event, is thought to be isolated slivers of oceanic crust left within the Gulf mantle. Their melting might have been triggered by the hot thermal regime linked to its opening, especially during the spreading stage of the Lower Tiburón basin, concomitant with volcanic activity in San Esteban (Calmus et al., 2008).

\subsection{Magnesian basalts, basaltic andesites and andesites: the "bajaite" suite}

Magnesian andesite suites are characterised by high contents in incompatible elements, although they display the relative depletion in $\mathrm{Nb}$ typical of calc-alkaline magmas. They include basalts, basaltic andesites and andesites $\left(\mathrm{SiO}_{2}<60\right.$ wt.\%) showing $\mathrm{MgO}$ and compatible transition elements $(\mathrm{Cr}, \mathrm{Co}, \mathrm{Ni})$ contents higher than expected from their silica contents (when compared to regular calc-alkaline series). A majority of them are rich in $\mathrm{Sr}$ (>1000 ppm) and their multielement patterns (Fig. 2c) show positive anomalies for this element, together with variable but often marked depletions in Y and HREE, which have been interpreted as indicative of an adakitic imprint (Defant and Drummond, 1990; "low-silica adakites" of Martin et al., 2005). In Baja California, these unusual lavas, which were termed "bajaites" by Rogers et al. (1985), form six volcanic fields delineating a $500 \mathrm{~km}$-long array parallel to the Gulf of California, from Jaraguay to La Purísima (Fig. 1). They cover a total 
surface of ca. $9000 \mathrm{~km}^{2}$ and range in age from Middle Miocene (14.6 Ma; Calmus et al., 2003;

Pallares et al., 2008) to Holocene in La Purísima (Bellon et al., 2006). They are moderately porphyritic, with 5 to 20 modal\% phenocrysts which include, by order of decreasing abundances, olivine, diopsidic clinopyroxene, orthopyroxene, labradorite, titanomagnetite, and occasional phlogopite and sanidine. They display easily recognizable geochemical characteristics: $\mathrm{SiO}_{2}$ up to $57 \%, \mathrm{MgO}$ up to $8 \%$, low $\mathrm{FeO} * / \mathrm{MgO}$ ratios usually less than 2, high $\mathrm{Na} / \mathrm{K}$, low $\mathrm{Rb} / \mathrm{Sr}(<0.01)$, very high contents in $\mathrm{Sr}$ (up to $3000 \mathrm{ppm})$ and $\mathrm{Ba}(>1000$ ppm), highly fractionated REE patterns (Fig. 2c), and relatively low ${ }^{87} \mathrm{Sr} /{ }^{86} \mathrm{Sr}<0.7048$ (Rogers et al., 1985; Saunders et al., 1987; Rogers and Saunders, 1989; Calmus et al., 2003).

Saunders et al. (1987) and Rogers and Saunders (1989) concluded that the genesis of the Baja California magnesian andesite suite was a two-stage process, involving mantle metasomatism by silicic melts during subduction followed by melting of this metasomatized mantle during a post-subduction (extensional) event. Calmus et al. (2003) and Pallares et al. (2008) proposed a detailed petrogenetic model involving melting of supraslab mantle having interacted with slab melts. In this model, reactions between adakitic melts and the deep supraslab mantle led to metasomatized pargasite-rich peridotites. Then, incongruent dehydration melting of pargasitic amphibole, at depths of ca. $80 \mathrm{~km}$, triggered the genesis of bajaitic melts, and left a garnet-rich residue. This melting occurred at minimal temperatures of $1050-1075^{\circ} \mathrm{C}$, consistent with a high thermal flux in the mantle wedge during the opening of an asthenospheric window following ridge-trench collision, as well as during the subsequent "no-slab" regime which followed the sinking of the Farallon plate into the deep mantle (Pallares et al., 2008). The model proposed by Castillo (2008) is rather similar to the former one, except that metasomatic mantle minerals are thought to result from the percolation of hydrous fluids rather than slab melts.

\subsection{Niobium-enriched basalts}

Niobium-enriched basalts (NEB) are an extremely unusual rock type, only found in close spatial and temporal association with Baja California adakites in Santa Clara, Vizcaíno Peninsula (11.7-8.7 Ma; Aguillón-Robles et al., 2001) and possibly in Santa Rosalía (11-9 Ma; Conly et al., 2005). In Santa Clara, they occur as fluidal lava flows of olivine-plagioclasephyric basalts which form horizontal mesas (Aguillón-Robles et al., 2001). They overlie adakitic pyroclastic flow deposits, some of which contain NEB blocks (Maury et al., 2009). 
These NEB are silica-oversaturated, highly sodic, and differ from the vast majority of arc basalts by their higher $\mathrm{Nb}(10-30 \mathrm{ppm})$ and $\mathrm{TiO}_{2}(1.3-1.8 \mathrm{wt} . \%)$ contents. They display rather smooth enriched incompatible element patterns culminating at the level of $\mathrm{Nb}$ (Fig. 2d), with variable positive anomalies in $\mathrm{Ba}, \mathrm{Sr}$ and $\mathrm{Ti}$ which are almost identical to those of the Philippine NEB (Sajona et al., 1996).

There is an ongoing debate regarding the genesis of these unusual basalts, which differ from the alkali basalts described below by their silica-saturated character, their generally lower enrichment in incompatible elements and their lower $\mathrm{Sr}$ isotopic ratios (AguillónRobles et al., 2001; Benoit et al., 2002). Unlike the magnesian andesite suite, they show neither negative $\mathrm{Nb}$ anomalies nor strong depletion in $\mathrm{Y}$ and HREE. The above authors thought these NEB to derive from the melting at relatively low pressures (depths of 40-60 $\mathrm{km})$, i.e. in the spinel stability field, of amphibole-rich supraslab mantle having interacted with adakitic melts (Defant et al., 1992; Kepezhinskas et al., 1996; Sajona et al., 1996). A major difference with the petrogenetic history of the magnesian andesite suite is that, for the latter, interactions between slab melts and the supraslab mantle occurred at greater depths (ca. $80 \mathrm{~km})$, i.e. in the garnet stability field. Castillo $(2008,2009)$ proposed an entirely different model, in which NEB of Baja California are genetically unrelated to adakites despite ample field evidence for their association (Maury et al., 2009). They are thought to result from the fractional crystallization of San Quintín-type melts coupled with their contamination by tholeiitic mantle materials and/or the Baja California continental crust. The San Quintín-type melts would have ascended through a slab window located beneath the Proto-Gulf of California should therefore have travelled ca. $150 \mathrm{~km}$ towards the fossil trench within the Baja lithospheric mantle. In addition, Santa Clara NEB are less radiogenic in Sr than San Quintín basalts, a feature hardly consistent with the contamination hypothesis (Maury et al., 2009).

\subsection{Alkali basalts and trachybasalts}

Alkali basalts in Baja California and Sonora are mostly Quaternary in age. In Baja California, the well-preserved San Quintín strombolian cones and associated flows, which contain peridotitic and granulitic xenoliths (Gastil et al., 1979) have been extensively studied (Luhr et al., 1995). Available ages range from 126 to $90 \mathrm{ka}$, but the eruptive activity probably continued into the Holocene. In Sonora, Quaternary alkali basalts and trachybasalts occur in 
two volcanic fields, where they are associated with tholeiitic basalts. In the Pinacate volcanic and 1.1 Ma. Then, the $1500 \mathrm{~km}^{2}$ Pinacate series magmas erupted until the Holocene $(13 \mathrm{ka}$; Turrin et al., 2008), forming hundreds of strombolian cones, maars and tuff rings (Gutmann, 2002) and emplacing tholeiitic, transitional and mildly alkali basalts together with trachybasalts and minor trachyandesites. The ca. $300 \mathrm{~km}^{2}$ Quaternary Moctezuma volcanic field (Paz Moreno et al., 2003) is located at the foothills of the Sierra Madre Occidental. It includes tholeiitic lava flows emitted during an early fissural event (1.7 Ma), overlain by younger $(0.53$ $0.44 \mathrm{Ma}$ ) alkali trachybasaltic lava flows erupted from small monogenetic cones.

Late Miocene alkali basalt-related lavas have only been described in northern Baja California. The two large plateaus (ca. $600 \mathrm{~km}^{2}$ each) of Mesa San Carlos and Mesa Santa Catarina, located along the west coast of Peninsula $100 \mathrm{~km}$ south of El Rosario, are capped by trachybasaltic (hawaiitic) flows dated between 9.3 and 7.5 Ma (Pallares et al., 2007).

Quaternary alkali basalts and trachybasalts from San Quintín, Pinacate and Moctezuma volcanic fields and Late Miocene San Carlos - Santa Catarina trachybasalts contain olivine, clinopyroxene, plagioclase, titanomagnetite and ilmenite. They are mildly silica-undersaturated (less than 5\% normative nepheline). Their multielement patterns (Fig. 2e) display a considerable enrichment in the most incompatible elements, culminating at the level of $\mathrm{Nb}$, and relative depletion in $\mathrm{Rb}, \mathrm{Ba}$ and $\mathrm{K}$. They are typical of an ocean island basalt (OIB)-type source with little or no crustal contamination (Luhr et al., 1995). Isotopic ( $\mathrm{Sr}, \mathrm{Nd}, \mathrm{Pb}$ ) data are only available for the Quaternary San Quintín (Luhr et al., 1995) Pinacate (Asmerom and Edwards, 1995; Goss et al., 2008) and Moctezuma (Paz Moreno et al., 2003) volcanic fields. They plot consistently within the OIB field, and evidences for crustal contamination are limited to two San Quintín cones. These alkali basaltic magmas are thought to derive from plume-type asthenospheric mantle (Asmerom and Edwards, 1995; Paz Moreno et al., 2003), at depths increasing from the spinel lherzolite field below San Quintín (Luhr et al., 1995) to the garnet lherzolite field below the Pinacate (Goss et al., 2008).

\subsection{Oceanic (MORB-type) basalts and related rocks}

Oceanic basalts in the studied area are exclusively Quaternary. Their occurrence is restricted to the Gulf of California, although Holocene tholeiitic dacites from the Cerro Prieto 
geothermal field, south of Mexicali, have been considered as MORB-related (Herzig, 1990). These oceanic basalts form the small Isla Tortuga, made of tholeiitic basaltic and ferrobasaltic flows (< 1.7 Ma; Batiza, 1978; Batiza et al., 1979) overlain by possibly Holocene hyaloclastic tuffs (Medina et al., 1989). They have also been found in several holes drilled during DSDP Leg 64 (Saunders et al., 1982a,b; Perfit et al., 1982; Fornari et al., 1982) along the Gulf rise (DSDP site 479) and in the Guaymas Basin (<0.4 Ma; DSDP sites 477, 478) and Yaqui Basin (DSDP site 481). These basalts range from subaphyric to sparsely porphyritic lavas containing phenocrysts of calcic plagioclase or olivine + plagioclase. Their major element compositions are broadly similar to those of normal MORB from the East Pacific Rise (EPR). Like the latter, they are poor in incompatible elements, and their flat to depleted multielement patterns (Fig. 2f) are consistent with their derivation from depleted asthenospheric sources similar to the EPR ones. However, the Sr contents of Guaymas Basin and Tortuga basalts are higher than those from basalts from the Gulf mouth area, and the former also display higher $\mathrm{La} / \mathrm{Yb}, \mathrm{Sr} / \mathrm{Zr}, \mathrm{Zr} / \mathrm{Ti}$ and $\mathrm{Th} / \mathrm{Hf}$ ratios, which suggest that their mantle source contained a "residual calc-alkaline component" (Saunders et al., 1982).

\subsection{Tholeiitic or transitional basalts and basaltic andesites}

Late Miocene tholeiitic basaltic andesites (11.3-7.2 Ma; Benoit et al., 2002; Bellon et al. 2006) crop out in Baja California, between San Juanico and San Ignacio, as very fluid flows overlying tilted Tertiary sedimentary rocks. They cap large sub-horizontal plateaus (mesas) and have probably been emitted from fissures. Similar tholeiitic lavas dated to 6 Ma have been collected in northern Baja California peninsula near 31²2’ N (El Paraiso, Aguillón-Robles, 2002). These tholeiitic rocks contain sparse plagioclase and olivine phenocrysts, are silicaoversaturated, and characterized by low $\mathrm{K}_{2} \mathrm{O}\left(<0.6\right.$ wt.\%) and rather high $\mathrm{TiO}_{2}(1.6-1.9$ wt.\%) contents. They are also richer in $\mathrm{Nb}$ and other HFSE than their calc-alkaline equivalents, and their rather flat REE and multielement patterns (Fig. 2g, bottom patterns) do not display any subduction imprint. Melting of depleted subslab mantle accounts satisfactorily for these flat patterns and depleted $\mathrm{Sr}$ and Nd isotopic signatures of these tholeiites (Benoit et al., 2002). However, a small sediment contribution is required to explain their enriched $\mathrm{Pb}$ isotopic features.

Three episodes of Neogene-Quaternary tholeiitic to transitional basaltic volcanism can be recognized in Sonora. During the Early Miocene (20.6-19 Ma) tholeiitic lava flows, which 
were later affected by extensional tectonics, were emplaced in the substratum of the Pinacate Volcanic Field (Vidal-Solano et al., 2008a) and in several sierras. These lavas contain less than $5 \%$ phenocrysts (olivine and plagioclase), and are olivine + hypersthene to quartz-normative basalts and basaltic andesites. Their multielement patterns (Fig. $2 \mathrm{~g}$, bottom patterns) are flat to slightly enriched. They display small negative $\mathrm{Nb}$ anomalies, which, together with their $\mathrm{Sr}$ and $\mathrm{Nd}$ isotopic signatures, suggest the involvement of lithospheric materials, possibly from a Precambrian lithospheric mantle source (Vidal-Solano et al., 2008a). Indeed, these rocks are rather similar to the lithospheric mantle-derived Early Miocene basalts of southern Nevada and westernmost Arizona, and the basaltic andesites from the Mojave Desert, California (Miller et al., 2000).

The second episode of tholeiitic to transitional magmatism in Sonora occurred during the Middle and Upper Miocene (Serravallian-Tortonian, 13.0-7.2 Ma). It emplaced lava flows in the Pinacate substratum (Paz Moreno et al., 2008), Las Trincheras (Mora-Klepeis and McDowell, 2004), and possibly, acording to Till et al. (2009)'s analyses, in Sierra Libre, Sierra El Aguaje, Coastal Sonora and Guaymas. This event was concomitant with the eruption in the same areas of peralkaline rhyolites and icelandites (see below), which are considered as derived from the open system fractional crystallization of such tholeiitic/transitional magmas (Vidal-Solano et al., 2005, 2007, 2008a,b). The mafic lavas from this episode display multielement patterns (Fig. 2g, upper group) more enriched than the older ones, with weaker $\mathrm{Nb}$ anomalies indicative of lithospheric contribution. Their $\mathrm{Sr}$ and $\mathrm{Nd}$ isotopic compositions are also closer to the MORB field (Vidal-Solano et al., 2008a). These features might traduce a temporal change in the composition of the mantle sources of the tholeiites, from shallow lithospheric to deeper asthenospheric mantle, as the result of convective thinning and extension of the Basin and Range lithosphere (Fitton et al., 1991; DePaolo and Daley, 2000; VidalSolano et al., 2008a).

Finally, tholeiitic basalts and basaltic andesites were also emplaced in Sonora during the Quaternary, in association with alkali basalts, in the Pinacate and Moctezuma volcanic fields (see section 3.6). They contain less than $10 \%$ olivine phenocrysts, and are either olivine + hypersthene or quartz-normative. Their main mineralogical difference with respect to the alkali basalts lies in the composition of clinopyroxenes. These are Ca-rich in the alkaline lavas and subcalcic with orthopyroxene or pigeonite in the tholeiitic lavas (Paz Moreno et al., 2003). The multi-element patterns of the tholeiitic lavas are subparallel to (although less enriched in the most incompatible elements) those of the associated alkali basalts and trachybasalts, and 
typical of their OIB affinity. Isotopic $(\mathrm{Sr}, \mathrm{Nd}, \mathrm{Pb})$ data on the Pinacate (Asmerom and

\subsection{Peralkaline rhyolites and icelandites}

Vidal-Solano (2005) and Vidal-Solano et al. (2005, 2007, 2008a,b) demonstrated that two rock types outcropping in central Sonora and the Puertecitos area in Baja California, and considered as calc-alkaline by other authors (Sawlan, 1991; Martín-Barajas et al., 1995; Till et al., 2009), are respectively peralkaline rhyolites (comendites) and icelandites. Both types commonly occur in tholeiitic to transitional basalt series erupted in extensional settings, and are generally thought to derive from the closed- or open-system fractional crystallization of the associated basaltic magmas. The Sonora and Puertecitos peralkaline rhyolites occur as ignimbrite deposits and less commonly as rhyolitic domes, and have been dated to 12.6-12 Ma (Vidal-Solano et al., 2008a,b). Most ignimbrite deposits have suffered some weathering, and thus their major element analyses do not show anymore the $(\mathrm{Na}+\mathrm{K}) / \mathrm{Al}$ ratios higher than unity which are characteristic of peralkaline rhyolites. Their Sr isotopic ratios indicate that they have also experienced limited contamination by the Precambrian substratum of Sonora (VidalSolano et al., 2008a,b). However, they have retained many typical features (Vidal-Solano et al., 2005, 2007), including (1) their unmistakable mineralogical association, with phenocrysts of fayalite, Fe-rich augite, alkali feldspar and zircon, (2) major element compositions characterized by high silica (>70 wt.\%), low alumina ( 12 wt.\%) and high alkalies, and (3) strong enrichment in the most incompatible elements, including the LREE, and marked depletion in $\mathrm{Ba}, \mathrm{Sr}$ and Eu typical of feldspar fractionation (Fig. 2h). Till et al. (2009) have published rhyolite analyses displaying similar characteristics from the Miocene volcanic fields of Suaqui Grande, Sierra Libre, Santa Ursula, Sierra El Aguaje, Sierra Mazatan and coastal Sonora, together with Ar-Ar ages (12.5-10.1 Ma) close to those of Vidal-Solano et al. (2008a). These rhyolitic sequences, more than 1000 m-thick in Sierra Santa Ursula, are interpreted as the first volcanic manifestation of the continental breakup of the Gulf of California. The main 
emission center of the 12.5 Ma old San Felipe Tuff is supposed to be located in the Sierra Kunkaak between Bahía de Kino and Punta Chueca (Oskin, 2002). However, the very large distribution of its deposits from San Felipe area in Baja California until Guaymas region and Central Sonora, as well as their variable thickness, may be due to the occurrence of several emission centers. The Lista Blanca Formation of La Colorada, Mazatán region and Tecoripa in Central Sonora, may correspond to the most distal pyroclastic deposits to the east.

In the same areas of central Sonora (e.g. in Sierra Lista Blanca and Sierra San Antonio), peralkaline comenditic ignimbrites are often capped by black porphyritic lava flows containing andesine, augite, pigeonite and Fe-Ti oxide phenocrysts set in a glassy groundmass (Vidal-Solano et al., 2008b). One of these flows yielded an Ar-Ar age of 10.9 $\pm 0.4 \mathrm{Ma}$. These rocks show major and trace element features typical of intermediate lavas from the tholeiitic basalt series (icelandites): intermediate silica contents (60-65 wt.\%), high total iron oxide (5-13 wt.\%) and $\mathrm{FeO} / \mathrm{MgO}$ ratios, together with $\mathrm{TiO}_{2}$ contents (> 1 wt.\%) higher than those of calcalkaline lavas. Their enriched incompatible element patterns (Fig. 2h) show negative anomalies in $\mathrm{Ba}, \mathrm{Sr}, \mathrm{Eu}$ and $\mathrm{Ti}$ weaker than those of the comendites (Vidal-Solano, 2005). Like the comendites, these icelandites also display small negative $\mathrm{Nb}$ anomalies and $\mathrm{Sr}, \mathrm{Nd}$ and $\mathrm{Pb}$ isotopic compositions consistent with minor assimilation of upper crustal Precambrian materials (Vidal-Solano et al., 2008a,b). Therefore, they are thought to derive from opensystem fractional crystallization of tholeiitic to transitional magmas. Till et al. (2009) have published andesite and dacite analyses with similar characteristics from the Miocene volcanic fields of Sierra Libre, Santa Ursula, Sierra El Aguaje and coastal Sonora, together with one ArAr age $(11.41 \pm 0.04 \mathrm{Ma})$ and several ages estimated by stratigraphic correlation for these rocks (12.2-11.1 Ma), which are close to that of the former authors.

\section{Discussion}

\subsection{Volcanism and tectonic reconstructions: spatial and temporal constraints}

There are two prerequisite conditions for reconstructing past tectonic regimes from the spatial and temporal patterns of volcanic activity described above. First, the geographic position of the volcanics should mark those of their sources at the time of their emplacement: in other words, most authors implicitely or explicitely assume that magmas ascend more or less 
vertically toward the surface from their ca. 50 to $100 \mathrm{~km}$ deep source, i.e. through the lithospheric mantle and the overlying crust. This assumption is consistent with current models of magma dynamics and emplacement in arcs as well as in intraplate extensional/transtensional settings and in rifts (Annen et al., 2006; Zellmer and Annen, 2008). In both cases, magmas are thought to ascend first as visco-elastic diapirs, and then to fill subvertical fracture networks within the brittle upper crustal rocks. However, Castillo (2008) claimed that basaltic magmas produced beneath the axis of the Proto-Gulf of California migrated laterally toward the fossil trench within the lithospheric mantle (1) $\sim 150 \mathrm{~km}$ below Santa Clara and Mesa San Carlos volcanic fields, and (2) $\sim 100 \mathrm{~km}$ below San Ignacio volcanic field (Fig. 1). This model has been questioned by Maury et al. (2009), who contended that corresponding magmas uprose through the Baja California asthenospheric window as proposed by previous authors (Benoit et al., 2002; Pallares et al., 2007).

The second condition is that the K-Ar and/or Ar-Ar ages of volcanic rocks could be taken as indicative of that of the tectonic event responsible for their genesis, i.e. that melts are not stored within the crust long enough to allow tectonic changes to occur between partial melting and emplacement. Based on a proposal by Cañón-Tapia and Walker (2004), NegreteAranda and Cañón-Tapia (2008) consider that Baja California melts could have been stored within either their source zones or the overlying lithosphere during $\sim 10^{6} \mathrm{yrs}$. Thus, there could be a significant decoupling between the tectonic regim deduced from their composition and that occurring at the time of their emplacement. The same hypothesis has been considered for Sonora lavas by Till et al. (2009) for subduction-related lavas post-dating by 4 Ma the end of the subduction of the Farallon plate at ca. 12.5 Ma. However, current thermal models predict that silicate melts can have segregation times (from their mantle or crustal source) in the range $10^{3}-10^{6}$ yrs, but ascent times that are geologically almost instantaneous (Annen et al., 2006). The largest volcanoes on Earth, i.e. the Hawaiian shield volcanoes, have an expected life time of $\sim 1 \mathrm{Ma}$ (DePaolo and Stolper, 1996), as examplified by the $\sim 0.65 \mathrm{Ma}$ time range obtained for the $3.1 \mathrm{~km}$ deep drilling in Mauna Kea volcano (Garcia et al., 2007). Of course, lower storage/residence time is likely to be expected for the much smaller Baja California and Sonora volcanoes.

The time span separating partial melting from cooling at the surface can also be evaluated using short-lived U-series isotopes (e.g. Hawkesworth et al., 2004). It is usually very short (a few $10^{3}$ yrs, or even less) for mafic magmas from intraplate settings (Sigmarsson et al., 2005) and arcs (Turner et al., 2001; Zellmer, 2008), e.g. for the Pinacate Quaternary basalts 
(Asmerom and Edwards, 1995). In arcs, it increases together with silica contents up to $10^{4}-10^{5}$ yrs, with $2 \times 10^{5}$ yrs $(0.2 \mathrm{Ma})$ as an usual upper limit for the more evolved rock types (Hawkesworth et al., 2004; Zellmer et al., 2005; Zellmer, 2008). This last time span is within the range of usual errors on K-Ar and Ar-Ar ages measured at ca. 10-12 Ma $( \pm 0.05$ to \pm 0.40 Ma). Therefore, we will in the following discussion consider these ages as representative of the times of partial melting of the mantle or crustal sources of Baja California and Sonora lavas.

\subsection{Insights from the distribution of lava types in northwestern Mexico}

The spatial distribution of the above-described lava types is rather striking (Fig. 1). Indeed, they usually occur within several hundred kilometers long belts subparallel to the fossil trench and to the axis of the Gulf of California. Five of these belts can be recognized. They are, from west to east: (1) a belt in clear fore-arc position, including the alkali basalts and trachybasalts from San Quintín and San Carlos - Santa Catarina, the Santa Clara adakites and NEB and the Santa Margarita adakites; (2) the "magnesian andesite belt" extending from Jaraguay to La Purísima and the San Juanico - San Ignacio tholeiitic basaltic andesites; (3) the Comondu calc-alkaline arc; (4) a set of Plio-Quaternary calc-alkaline islands and volcanoes located along the western Gulf margin (Isla San Luis, Tres Virgenes, La Reforma, Cerro Mencenares, Isla Coronado); and (5) the central part of the Gulf, including the MORB-type basalts from Guaymas Basin and Tortuga Island and the calc-alkaline and adakitic lavas of Isla San Esteban. Such a belt array is much less obvious in Sonora, although the tholeiitic/transitional lavas and the peralkaline rhyolites and icelandites occur within a broad NW-SE trending band (Fig. 1).

The main implication of the belt array distribution described above is that the EarlyMiddle Miocene organization of the Pacific-Farallon subduction zone controlled the distribution of the post-subduction (Late Miocene to Quaternary) volcanism throughout Baja California. Especially, adakites, NEB, magnesian andesites, tholeiitic andesites and alkali basalts/trachybasalts were emplaced on front-arc position with respect to the axis of the Comondú arc (Fig. 1). This feature suggests that the slab tearing process responsible for the ascent of subslab magmas occurred in front-arc position (Pallares et al., 2007) rather than in back-arc position, i.e. beneath the Proto-Gulf of California (Castillo, 2008). Another interesting feature is the back-arc position of Plio-Quaternary calc-alkaline and/or adakitic islands and volcanoes (Isla San Luis, Tres Virgenes, La Reforma, Cerro Mencenares, Isla Coronado), close 
to the axis of the Gulf, which may indicate that the thermal flux responsible for the partial melting of their sources was linked to the Gulf opening (Desonie, 1992; Bigioggero et al., 1987, 1995; Calmus et al., 2008).

\subsection{Spatial and temporal patterns of volcanism in northwestern Mexico}

4.3.1. Early-Middle Miocene (Aquitanian to Langhian): active subduction and Basin and Range tectonics

Prior to ca. $13 \mathrm{Ma}$, calc-alkaline magmatism was active in all the studied areas (Fig. 3a), where it built up the last volcanic edifices of the Comondú arc and several sierras in Sonora. Other geochemical groups were not represented in Baja California with the exception of a single magnesian andesite flow, 14.6 Ma old, in La Purísima (Bellon et al., 2006). In western Sonora, tholeiitic to transitional basalts and basaltic andesites, very similar to the lithospheric mantle-derived Early Miocene basalts of the Basin and Range province in the southwestern USA (Miller et al., 2000), were emplaced in several areas (Fig. 3a), e.g. in the substratum of the Pinacate and Moctezuma volcanic fields. Their geochemical signature is consistent with the involvement of lithospheric materials, possibly from a Precambrian lithospheric mantle source (Vidal-Solano et al., 2008a). Thus, their occurrences stake the southward prolongation of the Basin and Range extensional province (Paz Moreno et al., 2003; Vidal-Solano et al., 2008a). The lack of these tholeiitic to transitional lavas in Baja California is consistent with the fact that this area was not part of the Basin and Range province, as discussed above $(\S 2)$.

4.3.2. Middle to Late Miocene (Serravallian-Messinian): end of subduction and Basin and Range extension, slab-tearing and opening of an asthenospheric window

A major change is recorded at ca. 13 Ma throughout the studied area (Fig. 3b). Sporadic calc-alkaline activity persisted during the Late Miocene in several volcanic fields of Baja California and Sonora (until 5.8 Ma in Puertecitos, 7.3 Ma in Jaraguay and 8.3 Ma in Sierra El Aguaje) but it became volumetrically minor with respect to other lava types.

In Baja California, these include (1) lavas of presumed subslab mantle origin, such as the Mesa San Carlos and Mesa Santa Catarina trachybasalts (Pallares et al., 2007; Castillo, 
2008), the San Juanico - San Ignacio tholeiitic basaltic andesites (Benoit et al., 2002; Bellon et derived from the partial melting of the subducted Pacific-Farallon oceanic crust, i.e. Santa Clara adakites according to the interpretation of Aguillón-Robles et al. (2001) and followers (e.g. Maury et al., 2009); (3) lavas of presumed supraslab mantle origin, such as the volumetrically major magnesian andesites (Saunders et al., 1987; Calmus et al., 2003; Castillo, 2008; Pallares et al., 2008) and the Santa Clara NEB (Aguillón-Robles et al., 2001; Benoit et al., 2002); and finally (4) adakites derived from the mafic base of the Baja crust heated by subslab niobium-enriched melts, according to Castillo's $(2008,2009)$ model. Whatever the divergences regarding the sources of individual lava types, most authors (with the exception of Negrete-Aranda and Cañón-Tapia, 2008) agree that that the geochemical features of some of them suggest that they derive from the subslab (Pacific) asthenospheric mantle. Therefore, a tear-in-the-slab (evolving through time towards a slab window) is thought to have developed beneath the Peninsula at ca. $13 \mathrm{Ma}$ (Calmus et al., 2003; Bellon et al., 2006; Michaud et al., 2006; Pallares et al., 2007, 2008; Castillo, 2008, 2009; Maury et al., 2009). In addition to the ascent of subslab melts, it allowed the hot Pacific asthenosphere to flux into the window, and to trigger the melting of parts of the metasomatized supraslab mantle (e.g. of the sources of the magnesian andesite suite).

In Sonora, tholeiitic to transitional basalts and basaltic andesites were emplaced between 13 and 7.2 Ma in several volcanic fields, e.g. Pinacate and Las Trincheras (Fig. 3b). Their geochemical features suggest their derivation from deep asthenospheric mantle, uplifting as the result of convective thinning and extension of the Basin and Range lithosphere, and therefore a "no-slab" regime beneath coastal Sonora (Vidal-Solano et al., 2008a). The associated peralkaline rhyolites (12.6-12 Ma) and icelandites (10.9 Ma) are thought to derive from the open-system fractional crystallization of these basaltic magmas (Vidal-Solano et al., 2008a,b) coupled with minor assimilation of Precambrian continental crust.

The locations of the asthenosphere-derived Middle to Late Miocene lavas from Baja California and Sonora suggest that an about $200 \mathrm{~km}$ wide slab window parallel to the fossil trench developed between ca. 13-10 Ma from Mesa San Carlos, Mesa Santa Catarina and Santa Clara to the west towards Sierra de Mazatán and Sierra Lista Blanca to the east (Fig. 3b). The wider distribution of its magmatic markers in the northern part of the study area is consistent with its formation as a southern extension of the pre-existing Southern California window (Wilson et al., 2005; Michaud et al., 2006; Pallares et al., 2007; Vidal-Solano et al., 2008a,b; 
McCrory et al., 2009). However, available K-Ar and Ar-Ar data do not allow to track its from Sonora (Vidal-Solano, 2008a; Till et al., 2009) and southern Baja California (La Purísima; Bellon et al., 2006). The lack of Miocene adakites in Sonora and their occurrence in Santa Clara, Santa Rosalía and Jaraguay is consistent with their interpretation as slab melts. Indeed, oceanic metabasalts experience hydrous melting at relatively low pressures (1-2.5 GPa: Defant and Drummond, 1990; Martin, 1999; Martin et al., 2005) in hot subduction zones, where adakites are often found in front-arc position with respect to calc-alkaline lavas (Defant et al., 1992). Therefore, the Miocene Baja California adakites were likely to derive from the upper (i.e. shallow) lip of the slab window (Benoit et al., 2002; Pallares et al., 2007), which underwent partial melting triggered by its thermal erosion by the ascending hot subslab asthenosphere (Thorkelson, 1996; Thorkelson and Breitsprecher, 2005). On the contrary, this partial melting was unlikely to occur in the much deeper lower (eastern) lip of the window, beneath Sonora. The occurrence of magnesian andesites and NEB in Baja California and their lack in Sonora are consistent with this interpretation, providing that these lavas derive from the supraslab mantle metasomatized by adakitic melts (Benoit et al., 2002; Calmus et al., 2003; Pallares et al., 2008). The partial melting of this supraslab mantle has probably been triggered by the thermal input from the Pacific asthenosphere ascending through the slab window (Pallares et al., 2007, 2008; Castillo, 2008).

\subsubsection{Pliocene-Quaternary: opening of the Gulf and melting of slab slivers}

Young volcanic activity in the northern and northeastern parts of the Pacific Mexican margin emplaced Quaternary alkali basalts in San Quintín, and tholeiitic, transitional and mildly alkali basalts together with trachybasalts in Pinacate and Moctezuma volcanic fields (Fig. 3c). The incompatible element patterns and isotopic ( $\mathrm{Sr}, \mathrm{Nd}, \mathrm{Pb}$ ) compositions of these lavas are typical of their OIB affinity, and they are thought to derive from plume-type asthenospheric mantle (Asmerom and Edwards, 1995; Luhr et al., 1995; Paz Moreno et al., 2003; Goss et al., 2008).

The numerous Plio-Quaternary magnesian andesite fields which trend NNW-SSE along Baja California from Jaraguay to La Purísima (Figs. 1 and 3c) resulted from the dehydration melting of amphibole-rich supraslab mantle metasomatized by either adakitic melts and/or by hydrous fluids (Saunders et al., 1987; Calmus et al., 2003; Castillo, 2008; Pallares et al., 2008). 
With time, they became progressively depleted in Y and HREE, a feature consistent with the increase of the amount of residual garnet produced by the dehydration melting reaction (Pallares et al., 2008). The origin of the melting is attributed to the high thermal flux linked to the uprise of Pacific asthenosphere in the "no-slab" regime which followed the detachment and sinking of the deep part of the Farallon plate (Pallares et al., 2007, 2008; Castillo, 2008).

The fact that the Quaternary Gulf tholeiites from Isla Tortuga and Guaymas Basin differ from regular MORB by their selective enrichment in LILE and variable $\mathrm{Sr}$ isotopic ratios has been attributed to the presence of a "minor residual calc-alkaline component" in the mantle underlying the central and northern parts of the Gulf of California (Saunders et al., 1982a,b). In the same area, numerous Plio-Quaternary calc-alkaline and/or adakitic volcanoes trend along the western margin of the Gulf (Puertecitos, Isla San Luis, Tres Virgenes, La Reforma, El Aguajito, Cerro Los Mencenares, and Isla Coronado) and are even present in its central part (Isla San Esteban). Their occurrence suggests the presence below the Gulf area of slivers of subducted oceanic crust and of lithospheric mantle carrying a subduction-related geochemical imprint, due to its interaction with either slab-derived hydrous fluids or adakitic melts (Desonie et al., 1992; Calmus et al., 2008).

The Miocene tectonic and magmatic history of the area may account for the presence of slivers of oceanic crust and of subduction-modified mantle beneath the thinned continental crust of the central and northern Gulf of California. Prior to the opening of the Gulf, it was part of the western North American margin, and was underlain by the subducting Farallon plate from ca. 25 to $13 \mathrm{Ma}$. The subcontinental lithospheric mantle may then have interacted with slab-derived hydrous fluids. During the opening of the slab window and the following sinking of the deep part of the Farallon plate, slivers of oceanic crust may have been introduced within this lithospheric mantle beneath Isla San Esteban, and possibly Cerro Mencenares and Isla Coronado (Calmus et al., 2008). Indeed, Thorkelson (1996) and Thorkelson and Breitsprecher (2005) have shown that the slab edges of an asthenospheric window are able to either melt or to leave restite fragments, which may become long-term residents of the continental lithospheric mantle. Then, the lithospheric thinning and rupture linked to the Pliocene opening of the Gulf generated a high thermal regime, and asthenospherederived MORB-type tholeiites were emplaced in Isla Tortuga and in local spreading centres (Guaymas Basin, Lower Tiburón?). During their ascent, they interacted with the subductionmodified lithospheric mantle and were enriched in LILE, LREE and radiogenic Sr. The high thermal regime associated to asthenospheric uprise also induced partial melting of the Gulf 
heterogeneous lithospheric mantle, generating calc-alkaline basalts and basaltic andesites, or alternatively adakites from slivers of oceanic crust incorporated within this mantle (Calmus et al., 2008).

\section{Conclusions}

1. Prior to $13 \mathrm{Ma}$, the Neogene magmatic activity in northwestern Mexico, linked to the subduction of the Pacific-Farallon oceanic plate, emplaced the widespread and relatively homogeneous calc-alkaline Comondú and central coast of Sonora volcanic arc. In the extensional domain of western Sonora, tholeiitic to transitional basalts and basaltic andesites, very similar to the lithospheric mantle-derived Early Miocene basalts of the Basin and Range province in the southwestern USA, were emplaced in several areas (Fig. 3a).

2. The end of the Farallon subduction was marked by the emplacement of much more complex Middle to Late Miocene volcanic associations (Fig. 3b), between 13 and 7 Ma. Sporadic calc-alkaline activity persisted in Baja California (BC) and Sonora (SO), but became volumetrically minor with respect to other lava types. These include (a) lavas of presumed subslab mantle origin, such as alkali trachybasalts (BC), asthenosphere-derived tholeiitic/transitional basalts and basaltic andesites (BC, SO), and peralkaline rhyolites (comendites) and icelandites resulting from the open system fractional crystallization of these basaltic magmas (SO); (b) adakites derived from the partial melting of the subducted PacificFarallon oceanic crust (BC); and (c) magnesian andesites and niobium-enriched basalts (BC) derived from the melting of supraslab mantle metasomatized by adakitic melts.

3. We show that the spatial and temporal distribution of these lava types is consistent with the development of a slab tear, evolving into a $200 \mathrm{~km}$-wide slab window parallel to the fossil trench, within the young part of the subducted plate. Tholeiitic, transitional and alkali basalts of subslab origin ascended through this window (BC, SO), and adakites (BC) derived from the partial melting of the upper lip of the slab window triggered by its thermal erosion by the ascending hot subslab asthenosphere. The latter also triggered the melting of the hydrous fluid and/or slab melt-metasomatized supraslab mantle, generating calc-alkaline lavas (BC, SO), magnesian andesites (BC) and NEB (BC). The extension of the slab window below the continent is difficult to determine because it is controlled by several kinematic and geologic 
parameters. The first one is the geometry of the connection with the southern California asthenospheric window. The good fit between the location of the southern limit of the latter (Wilson et al., 2005) and the northern limit of the Baja California slab window proposed by Pallares et al. (2007) suggests that both slab windows are connected, and that the southern one is a younger extension of the northern and older one. In the case of the California slab window, it is possible to evaluate the velocity of opening based on the spreading ridge rate prior to ridge subduction, and on the spreading rate of remaining active ridge segments between Pacific and Farallon or between fragmented plates, such as the Guadalupe or Magdalena microplates. On the contrary, below northwestern Mexico, no ridge subduction occurred and spreading along the ridge segments decreased between 12 and ca. 8 Ma west of southern Baja California peninsula. Then the opening rate of the slab window would depend of the sinking velocity of the eastern Farallon slab root, and of the possible retreat of Guadalupe and Magdalena to the west with respect to Baja California. The hypothesis of an initiating slab window at ca. 12.5 Ma below southernmost Baja California is proposed also by Fletcher et al. (2007) in their tectonic evolution model depicted by three schematic cross sections at $16,15-13$, and $12.5 \mathrm{Ma}$ at the latitude of the Magdalena fan. At 15-13 Ma these authors hypothesize a breakup of the slab below the Comondú arc, where the dip of the slab increases.

The Middle and Late Miocene volcanism in Baja California is very different from the contemporaneous volcanism in Sonora. Two reasons can be reasonably proposed to explain such a difference. In Baja California, thermal conditions allowed the partial melting of the subducted Magdalena plate and generation of adakite and magnesian andesite. Below Sonora, on one hand, the depth and temperature of the subducted slab were incompatible with the formation of such magmas. On the other hand, the presence of tholeiitic to transitional basalts and derived peralkaline rhyolites and icelandites in Sonora are related to the continental Basin and Range extension which did not occur in Baja California, west of the Main Gulf Escarpment. Nevertheless, the age of this silicic magmatism and its distribution mainly along the western margin of the Gulf of California suggest that it was probably triggered by the initiation of breakup of the Gulf Extensional Province.

4. During the Plio-Quaternary (Fig. 3c), the "no-slab" regime following the sinking of the old part of the Farallon plate within the deep mantle allowed the emplacement of OIB-type tholeiitic/transitional (SO) and alkali basalts ( $\mathrm{BC}, \mathrm{SO})$ of deep asthenospheric origin. The lithospheric thinning and rupture linked to the opening of the Gulf of California (GC) generated a high thermal regime associated to asthenospheric uprise, and emplaced depleted 
MORB-type tholeiites (GC). This thermal regime also induced partial melting of the

\section{ACKNOWLEDGEMENTS}

Fieldwork and analytical expenses were funded by the French-Mexican ECOS project, by the Centre National de la Recherche Scientifique (CNRS) and the Universite de Bretagne Occidentale (Unité Mixte de Recherche 6538 "Domaines océaniques"). The Instituto de Geología of the Universidad Autónoma de San Luis Potosí and the Estación Regional del Noroeste (ERNO), Instituto de Geología of the Universidad Nacional Autónoma de México also provided financial support for fieldwork. We thank Jesus Vidal-Solano for the communication of data on Sonora volcanism and for many enthusiastic discussions on the slab window models.

\section{REFERENCES CITED}

Aguillón-Robles, A. (2002), Subduction de dorsale et évolution du magmatisme associé: exemple de la Basse Californie (Mexique) du Miocène au Quaternaire, Thèse de Doctorat, Université de Bretagne Occidentale, Brest (France) 214p. + annexes.

Aguillón-Robles, A., Calmus, T., Benoit, M., Bellon, H., Maury, R.C., Cotten, J., Bourgois, J., and Michaud, F. (2001), Late Miocene adakites and Nb-enriched basalts from Vizcaino 
Peninsula, Mexico: indicators of East Pacific Rise subduction below southern Baja California ?, Geology 29, 531-534.

Alonso-Perez R., Müntener O., and Ulmer P. (2009), Igneous garnet and amphibole fractionation in the roots of island arcs: experimental constraints on $\mathrm{H}_{2} \mathrm{O}$ undersaturated andesitic liquids, Contrib. Mine. Petrol. 157, 541-558.

Annen, C., Blundy, J.D., and Sparks, R.S.J. (2006), The genesis of intermediate and silicic magmas in deep crustal hot zones, J. Petrology 47, 505-539.

Arculus, R. J. (1994), Aspects of magma genesis in arcs, Lithos 33, 189-208.

Arculus, R. J., Lapierre, H., and Jaillard, E. (1999), Geochemical window into subduction and accretion processes: Raspas metamorphic complex, Ecuador, Gology 27, 547-550.

Asmerom, Y., and Edwards, E.L. (1995), U-series isotope evidence for the origin of continental basalts, Earth Plan. Sc. Lett. 134, 1-7.

Atherton, M. P., and Petford, N. (1993), Generation of sodium-rich magmas from newly underplated basaltic crust, Nature 362, 144-146.

Atwater, T., and Stock, J. (1998), Pacific-North American plate tectonics of the Neogene southwestern United States: an update, Inter. Geol. Rev. 40, 375-402.

Batiza, R. (1978), Geology, petrology, and geochemistry of Isla Tortuga, a recently formed tholeiitic island in the Gulf of California, Geol. Soc. Amer. Bull. 89, 1309-1324.

Batiza R., Futa K., and Hedge C. E. (1979), Trace element and strontium isotope characteristics of volcanic rocks from Isla Tortuga: A young seamount in the Gulf of California, Earth Plan. Sc. Lett. 43, 269-278.

Bellon, H., Aguillón-Robles, A., Calmus, T., Maury, R.C., Bourgois, J., and Cotten, J. (2006), La Purisima Volcanic Field, Baja California Sur, Mexico: Mid-Miocene to Recent volcanism in relation with subduction and asthenospheric window opening, J. Volcan. Geother. Res. 152, 253-272, doi:10.1016/j.jvolgeores.2005.10.005.

Benoit, M., Aguillón-Robles, A., Calmus, T., Maury, R.C., Bellon, H., Cotten, J., Bourgois, J., and Michaud, F. (2002), Geochemical diversity of Late Miocene volcanism in southern Baja California, Mexico: Implication of mantle and crustal sources during the opening of an asthenospheric window, J. Geology 110, 627-648, doi:10.1086/342735.

Bigioggero, B., Capaldi, G., Chiesa, S., Montrasio, A., Vezzoli, L., and Zanchi, A. (1987), Post-subduction magmatism in the Gulf of California: The Isla Coronados (Baja California Sur, Mexico), Inst. Lombardo (Rendiconti Scienze) B121, 117-132. 
Bigioggero, B., Chiesa, S., Zanchi, A., Montrasio, A., and Vezzoli, L. (1995), The Cerro Mencenares volcanic center, Baja California Sur: Source and tectonic control on postsubduction magmatism within the Gulf Rift, Geolog. Soc. Am. Bull. 107, 1108-1122.

Bonini, A.J., and Baldwin, S.L. (1998), Mesozoic metamorphic and middle to late Tertiary magmatic events on Magdalena and Santa Margarita Islands, Baja California Sur, Mexico: Implications for the tectonic evolution of the Baja California continental borderland, Geolog. Soc. Am. Bull. 110, 1094-1104.

Calmus, T., Aguillón-Robles, A., Maury, R.C., Bellon, H., Benoit, M., Cotten, J., Bourgois, J., and Michaud, F. (2003), Spatial and temporal evolution of basalts and magnesian andesites ("bajaites") from Baja California, México: The role of slab melts, Lithos 66, 77-105, doi: 10.1016/S0024-4937(02)00214-1.

Calmus, T., Pallares, C., Maury, R.C., Bellon, H., Pérez-Segura, E., Aguillón-Robles, A., Carreno, A.-L., Bourgois, J., Cotten, J., and Benoit, M. (2008), Petrologic diversity of Plio-Quaternary post-subduction volcanism in Baja California: an example from Isla San Esteban (Gulf of California, México), Bull. Soc. Géolog. France 179, 465-481, doi: 10.2113/gssgfbull.179.5.465.

Calmus, T., Poupeau, G., Defaux, J., and Labrin, E. (1997), Apatite fission track ages in Sonora, Mexico: A recording of Basin and Range events and opening of the Gulf of California, GEOS 18-4, 293.

Cameron, K.L., and Cameron, M. (1985), Rare earth element, ${ }^{87} \mathrm{Sr}{ }^{86} \mathrm{Sr}$, and ${ }^{143} \mathrm{Nd} /{ }^{144} \mathrm{Nd}$ compositions of Cenozoic orogenic dacites from Baja California, northwestern Mexico, and adjacent west Texas: evidence for the predominance of a subcrustal component, Contrib. Mineral. Petrol. 91, 1-11.

Cañón-Tapia, E., and Walker, G.P.L. (2004), Global aspects of volcanism: the perspectives of "plate tectonics" and "volcanic systems", Earth Sc. Rev. 66, 163-182.

Castillo, P.R. (2008), Origin of the adakite-high Nb basalt association and its implications for post-subduction magmatism in Baja California, Mexico, Geolog. Soc. Am. Bull. 120, 451-462.

Castillo, P.R. (2009), Origin of Nb-enriched basalts and adakites in Baja California, Mexico, revisited: Reply, Geolog. Soc. Am. Bull. 121, 1470-1472.

Chiaradia M., Müntener O., Beate B., and Fontignie D. (2009), Adakite-like volcanism od Ecuador: lower crust magmatic evolution and recycling, Contrib. Miner. Petrol. 158, 563-588. 
Conly, A.G., Brenan, J.M., Bellon, H., and Scott, S.D. (2005), Arc to rift transitional volcanism in the Santa Rosalía Region, Baja California Sur, Mexico, J. Volcan. Geotherm. Res. 142, 303-341.

Consejo de Recursos Minerales (CRM), (1992), Monografía geológica-minera del Estado de Sonora, Secretaría de Energía, Minas e Industria Paraestatal, 220 p., + anexos.

Cotten, J., Le Dez, A., Bau, M., Caroff, M., Maury, R., Dulski, P., Fourçade, S., Bohn, M., and Brousse R. (1995), Origin of anomalous rare-earth element and yttrium enrichments in subaerially exposed basalts: Evidence from French Polynesia, Chemical Geology 119, 115-138.

Defant, M.J., and Drummond, M.S. (1990), Derivation of some modern arc magmas by melting of young subducted lithosphere, Nature 347, 662-665.

Defant, M.J., Jackson, T.E., Drummond, M.S., de Boer, J.Z., Bellon, H., Feigenson, M.D., Maury, R.C., and Steward, R.H. (1992), The geochemistry of young volcanism throughout western Panama and southeastern Costa Rica: an overview, J. Geolog. Soc. London 149, 569-579.

Defant, M.J., and Kepezhinskas, P. (2001), Evidence suggests slab melting in arc magmas, EOS (Am. Geophys. Union Transactions) 82, 67-69.

Demant, A., (1984), The Reforma Caldera, Santa Rosalía area, Baja California. A volcanological, petrographical and mineralogical study. In Neotectonics and sea level variations in the Gulf of California area, Symposium, Universidad Nacional Autónoma de México, Instituto de Geología, 75-96.

Desonie, D.L., (1992), Geological and geochemical reconnaissance of Isla San Esteban: postsubduction orogenic volcanism in the Gulf of California, J. Volcan. Geotherm. Res. 52, 123-140.

Defant, M.J., and Drummond, M.S. (1990), Derivation of some modern arc magmas by melting of young subducted lithosphere, Nature 347, 662-665.

DePaolo, D.J., and Daley, E.E. (2000), Neodymium isotopes in basalts of the southwest Basin and Range and lithospheric thinning during continental extension, Chemical Geology $169,157-185$.

DePaolo, D.J., Stolper, E.M. (1996), Models of Hawaiian volcano growth and plume structure: Implications of results from the Hawaii Scientific Drilling Project, J. Geophys. Res. 101, 11643-11654. 
Dokka, R.K., Merriam, R.H. (1982), Late Cenozoic extension of northeastern Baja California, Mexico, Geolog. Soc. Am. Bull. 93, 371-378.

Dyment, J. (2003), Anomalies magnétiques et datations des fonds océaniques: quarante ans après Vine et Matthews, Rapport quadriennal 2000-2003 du Comité National Français de Géodésie et de Géophysique (CNFGG), 160-179.

Fletcher, J.M., Grove, M., Kimbrough, D., Lovera, O., and Gehrels, G.E. (2007), Ridgetrench interactions and theNeogene tectonic evolution of the Magdalena Shelf and southern Gulf of California: insights from detrital zircon $U-P b$ ages from the Magdalena Fan and adjacent areas, Geolog. Soc. Amer. Bull. 119 (11-12), 1313-1336.

Fornari, D.J., Saunders, A.D., and Perfit, MR. (1982), Major-element chemistry of basaltic glasses recovered during deep-sea drilling project LEG-64, Initial reports of the Deep Sea Drilling Project 64, 649-666.

Fitton, J.G., James, D., and Leeman, W.P. (1991), Basic magmatism associated with late Cenozoic extension in the western Unites States: compositional cariations in time and space, J. Geophys. Res. 96 (13), 693-13,711.

Gabb, W.M. (1882), Notes on the Geology of Lower California, Geolog. Survey California, II, Sec. H, Cambridge Mass, John Wilson \& Son, pp. 137-148

Gans, P.B. (1997), Large-magnitude Oligo-Miocene extension in southern Sonora: Implications for the tectonic evolution of northwest Mexico, Tectonics, 16 (3), 388-408.

Garcia, M.O., Haskins, E.H., Stolper, E.M., and Baker, M. (2007), Stratigraphy of the Hawaii Scientific Drilling Project core (HSDP2): Anatomy of a Hawaiian shield volcano, Geochem. Geophys. Geosystems 8 (2), Q02G20, doi:10.129/2006GC001379.

Garduño-Monroy, V.H., Vargas-Ledezma, H., and Campos-Enriquez, J.O. (1993), Preliminary geologic studies of Sierra El Aguajito (Baja California, Mexico): a resurgent-type caldera, J. Volcan. Geotherm. Res. 59 (1-2), 47-58.

Gastil, G., Krummenacheer, D., and Minch, J. (1979), The record of Cenozoic volcanism around the Gulf of California, Geolog. Soc. Am. Bull. 90, 839-857.

Gastil, R.G., Phillips, R.P., and Allison, E.C. (1975), Reconnaissance geology of the state of Baja California, Geolog. Soc. Am. Memoir, 140-170.

Goss, A.R., Gutmann, J.T., Varekamp, J.C., and Kamenov, G. (2008), Pb isotopes and trace elements of the Pinacate volcanic field, northwestern Sonora, Mexico: a Basin and Range mini-plume near the EPR spreading center, Geolog. Soc. Am. Abstracts with Programs 40, pp. 530. 
Gutmann, J.T. (2002), Strombolian and effusive activity as precursors to phreatomagmatism: Eruptive sequence at maars of the Pinacate volcanic field, Sonora, Mexico, J. Volcan. Geotherm. Res. 113, 345-356.

Hausback, B.P. (1984), Cenozoic volcanism and tectonic evolution of Baja California Sur, Mexico, In (Frizzell V.A. Jr. Ed.), Geology of the Baja California Peninsula. Pacific Section, Soc. Econ. Paleontol. Mineralog. 39, pp. 219-236.

Hawkesworth, C.J., George R., Turner, S., and Zellmer, G. (2004), Time scales of magmatic processes, Earth Plan. Sc. Lett. 218, 1-16.

Henry, C.D. (1989), Late Cenozoic Basin and Range structure in western Mexico adjacent to the Gulf of California, Geolog. Soc. Am. Bull. 101, 1147-1156.

Henry, C.D., and Aranda Gómez, J. J. (2000). Plate interactions control middle-late Miocene, proto-Gulf and Basin and Range extension in the southern Basin and Range, Tectonophysics 318, 1-26.

Herzig, C.T. (1990). Geochemistry of igneous rocks from the Cerro Prieto geothermal field, northern Baja California, Mexico, J. Volcan. Geotherm. Res. 42, 261-271.

Jego, S., Maury, R.C. Polvé, M., Yumul Jr., G.P., Bellon, H., Tamayo Jr., R.A., and Cotten, J. (2005), Geochemistry of adakites from the Philippines: Constraints on their origins, Resource Geology 55, 163-187.

Kepezhinskas, P.K., Defant, M.J., and Drummond, M.S. (1996), Progressive enrichment of island arc mantle by melt-peridotite interaction inferred from Kamchatka xenoliths, Geochim. Cosmoch. Acta 60, 1217-1229.

Le Bas, M.J., Le Maitre, R.W., Streckeisen, A., and Zanettin, B. (1986), A chemical classification of volcanic rocks based on the total alkali-silica diagram, J.Petrol. 27, 745-750.

Lee, J., Miller, M.M., Crippen, R., Hacker, B., and Ledesma-Vazquez, J. (1996), Middle Miocene extension in the Gulf Extensional Province, Baja California: Evidence from the suthern Sierra Juarez, Geolog. Soc. Am. Bull. 108, 505-525.

Lonsdale, P. (1991), Structural patterns of the Pacific floor offshore of peninsular California, In (Dauphin, J.P., Simoneit, B.A. Eds.), The Gulf and Peninsular Province of the Californias, Am. Ass. Petrol. Geolog. Memoir 47, pp. 87-125.

Luhr, J.F., Aranda-Gómez, J.J., and Housh, T.B. (1995), San Quintin Volcanic field, Baja California Norte, México. Geology, petrology, and geochemistry, J. Geophys. Res. 100, $10,353-10,380$. 
Macpherson, C.G., Dreher, S.T., and Thirlwall, M.F. (2006), Adakites without slab melting: high pressure differentiation of island arc magma, Mindano, the Philippines, Earth Plan. Sc. Lett. 243, 581-593.

Martin, H., (1999), Adakitic magmas: modern analogues of Archean granitoids, Lithos 46, 411-429.

Martin, H., Smithies, R.H., Rapp, R., Moyen, J.-F., and Champion, D. (2005), An overview of adakite, tonalite-trondhjemite-granodiorite (TTG), and sanukitoid: relationships and some implications for crustal evolution, Lithos 79, 1-24.

Martín, A., Fletcher, J.M., López-Martínez, M., and Mendoza-Borunda, R. (2000), Waning Miocene subduction and arc volcanism in Baja California: the San Luis Gonzaga volcanic field, Tectonophysics 318, 27-51.

Martin, H., Smithies, R.H., Rapp, R., Moyen, J.-F., and Champion, D. (2005), An overview of adakite, tonalite-trondhjemite-granodiorite (TTG), and sanukitoid: relationships and some implications for crustal evolution, Lithos 79, 1-24.

Maury, R.C., Calmus, T., Pallares, C., Benoit, M., Grégoire, M., Aguillón-Robles, A., Bellon, H., and Bohn, M. (2009), Origin of the adakite-high Nb basalt association and its implications for post-subduction magmatism in Baja California, Mexico: Discussion, Geolog. Soc. Am. Bull. 122, 1465-1469, doi: 10.1130/B30043.1.

McCrory, P.A., Wilson, D.S., and Stanley, R.G. (2009), Continuing evolution of the PacificJuan de Fuca-North America slab window system - A trench-ridge-transform example from the Pacific rim, Tectonophysics 464, 30-42.

Medina, F., Suarez, F., and Espindola, J.M. (1989), Historic and Holocene volcanic centers in NW Mexico, A supplement to the IAVCEI catalogue, Bull. Volcan. 51, suppl. 1, 91-93.

Michaud, F., Royer, J.-Y., Bourgois, J., Dyment, J., Calmus, T., Bandy, W., Sosson, M., Mortera-Gutiérrez, C., Sichler, B., Rebolledo-Viera, M., and Pontoise, B. (2006), Oceanic-ridge subduction vs. slab break-off: plate tectonic evolution along the Baja California Sur continental margin since 15 Ma, Geology 34, 13-16.

Middlemost, E.A.K. (1975), The basalt clan. Earth Sciences Review 11, 337-364.

Miller, J.S., Glazner, A.F., Farmer, G.L., Suayah, I.B., and Keith, L.A. (2000), A Sr, $N d$, and $\mathrm{Pb}$ isotopic study of mantle domains and crustal structure in the Mojave Desert, California, Geolog. Soc. Am. Bull. 112, 1264-1279. 
Mora-Klepeis, G., and McDowell, F. (2004), Late Miocene calc-alkaline volcanism in northwestern México: an expression of rift or subduction-related magmatism?, J. South Am. Earth Sc. 17, 297-310.

Müntener O., and Ulmer P. (2006), Experimentally derived high-pressure cumulates from hydrous arc magmas and consequences for the seismic velocity structure of lower arc crust, Geophys. Res. Lett. 33, L21308, doi:10.129/2006GL027629.

Negrete-Aranda, R., and Cañón-Tapia, E. (2008), Post-subduction volcanism in the Baja California Peninsula, Mexico: the effects of tectonic reconfiguration in volcanic systems, Lithos 102, 392-414.

Ortega-Gutiérrez, F., Mitre-Salazar, L.M., Roldan-Quintana, J., Aranda-Gómez, J.J., MoranZenteno, D., Alanis-Alvarez, S., and Nieto-Samaniego, A. (1992), Carta geológica de la República Mexicana, escala 1:2,000,000, quinta edición, Instituto de Geología UNAM y Sría. Energía e Industria Paraestatal, CRM, mapa + texto explicativo, 74 pp.

Oskin, M. (2002), Tectonic evolution of the northern Gulf of California, Mexico, deduced from conjugated rifted margins of the Upper Delfin basin, Ph.D. Thesis, Pasadena, California Institute of Technology, $481 \mathrm{pp}$.

Oskin, M., Stock, J. (2003), Cenozoic volcanismand tectonics of the continental margins of the upper Delfin Basin, northeastern Baja California and western Sonora, In (Johnson, S.E. et al. Eds.), Tectonic Evolution of Northwestern Mexico and the Southwestern USA, Geolog. Soc. Am. Spec. Paper 374, pp. 421-438.

Pallares, C., Maury, R.C., Bellon, H., Royer, J.Y., Calmus, T., Aguillón-Robles, A., Cotten, J., Benoit, M., Michaud, F., and Bourgois, J. (2007), Slab-tearing following ridgetrench collision: Evidence from Miocene volcanism in Baja California, México, J. Volcan. Geotherm. Res. 161, 95-117, doi: 10.1016/j.jvolgeores.2006.11.002, doi:10.1016/j.lithos.2008.03.004.

Pallares, C., Bellon, H., Benoit, M., Maury, R.C., Aguillón-Robles, A., Calmus, T., and Cotten, J. (2008), Slab-tearing following ridge-trench collision: Evidence from Miocene volcanism in Baja California, México, Lithos 105, 162-180.

Paz-Moreno, F. A., and Demant, A. (1999), The Recent Isla San Luis volcanic center: Petrology of a rift-related volcanic suite in the northern Gulf of California, Mexico, J. Volcan. Geotherm. Res. 93, 31-52.

Paz-Moreno, F. A., Demant, A., Cochemé J.-J., Dostal, J., and Montigny, R. (2003), The Quaternary Moctezuma volcanic field: A tholeiitic to alkali basaltic episode in the 
central Sonora Basin and Range Province, Mexico, In (Johnson, S. E., Paterson S.R., Fletcher, J. M., Girty, G. H., Kimbrough, D. L., Martín-Barajas, A., eds.) Tectonic evolution of northwestern México and southwestern USA, Geolog. Soc. Am. Sp. Paper $374,439-455$.

Peccerillo, A., and Taylor, S.R. (1976), Geochemistry of Eocene calc-alkaline volcanic rocks from the Kastamonu area, northern Turkey, Contrib. Mineral. Petrol. 58, 63-81.

Perfit, M.R., Saunders, A.D., and Fornari, D.J. (1982), Phase chemistry, fractional crystallization, and magma mixing in basalts from the Gulf of California, deep-sea drilling project LEG-64, Initial reports of the Deep Sea Drilling Project 64, 649-666.

Petford, N., and Atherton, M. P. (1996), Na-rich partials melts from newly underplated basaltic crust: the Cordillera Blanca Batholith, Peru, J. Petrol. 37, 1491-1521.

Prouteau, G., and Scaillet, B. (2003), Experimental constraints on the origin of the 1991 Pinatubo dacite, J. Petrol. 44, 2203-2241.

Rogers, G., and Saunders, A.D. (1989), Magnesian andesites from Mexico, Chile and the Aleutian Islands: Implications for magmatism associated with ridge-trench collisions, In (Crawford, A.J. Ed.), Boninites and related rocks, London, Unwin Hyman, pp. 416-445.

Rogers, G., Saunders, A.D., Terrell, D.J., Verma, S.P., and Marriner, G.F. (1985), Geochemistry of Holocene volcanic rocks associated with ridge subduction in Baja California, Mexico, Nature 315, 389-392.

Roldán-Quintana, J., Mora-Alvarez, G., Calmus, T., Valencia-Moreno, M., and LozanoSantacruz, R. (2004), El Graben de Empalme, Sonora, México: Magmatismo y tectónica extensional asociados a la ruptura inicial del Golfo de California, Rev. Mex, Cienc. Geológ. 21 (3), 320-334.

Sajona, F.G., Maury, R.C., Bellon, H., Cotten, J., and Defant, M. (1996), High field strength element enrichment of Pliocene-Pleistocene island arc basalts, Zamboanga Peninsula, western Mindanao (Philippines), J. Petrol. 37, 693-726.

Saunders, A.D., Fornari, D. J., Joron, J.L., Tarney, J., Treuil, M. 1982a. Geochemistry of basic igneous rocks, Gulf Of California, Deep Sea Drilling Project Leg. 641. In: J. Blaklee, L.W. Platt and L.N. Stout, Eds, Initial Reports of Deep Sea Drilling Project, Washington, 64, part 2, 595-642.

Saunders, A. D., Fornari, D. J., and Morrisson, M.A. (1982b), The composition and emplacement of basaltic magmas produced during the development of continentalmargin basins: The Gulf of California, Mexico, J. Geol. Soc. London 139, 335-346. 
Saunders, A.D., Rogers, G., Marriner, G.F., Terrell, D.J., and Verma, S.P. (1987), Geochemistry of Cenozoic volcanic rocks, Baja California, Mexico: Implications for the petrogenesis of post-subduction magmas, J. Volcan. Geotherm. Res. 32, 223-245.

Sawlan, M.G. (1991), Magmatic evolution of the Gulf of California rift, In (Dauphin, J.P., Simoneit, B.A. Eds.), The Gulf and Peninsular Province of the Californias, Am. Ass. Petrol. Geolog. Memoir 47, pp. 301-369.

Sawlan, M.G., and Smith, J.G. (1984), Petrologic characteristics, age and tectonic setting of Neogene volcanic rocks in northern Baja California Sur, Mexico, In (Frizzel, V.A, Jr., Ed.), Geology of the Baja California Peninsula: Pacific Section, Soc. Econ. Paleontol. Mineralogist, pp. 237-251.

Schmitt, A.K., Stockli, D.F., and Hausback, B.P. (2006), Eruption and magma crystallization ages of Las Tres Virgenes (Baja California) constrained by combined ${ }^{230} \mathrm{Th}^{238} U$ and $(U$ Th)/He dating of zircon, J. Volcan. Geother. Res. 158, 281-295.

Sen, C., and Dunn, T. (1994a), Dehydration melting of a basaltic composition amphibole at 1.5 and 2.0 Gpa: implication for the origin of adakites, Contrib. Mineral. Petrol. 117, 394409.

Sigmarsson, O., Condomines, M., and Bachèlery, P. (2005), Magma residence time beneath the Piton de la Fournaise volcano, Reunion Island, from U-series disequilibria, Earth Planet. Sci. Lett. 234, 223-234.

Sonder, L.J., Jones, C.H. (1999), Western United States extension: How the West was widened, Annual Rev. Earth Planet. Sci. 27, 417-462.

Spencer, J. E., and Normark, W. R. (1989), Neogene plate-tectonic evolution of the Baja California Sur continental margin and the southern Gulf of California, Mexico,: In (Winterer, E.L., Hussong, D. M., Decker, R. W. Eds.), The eastern Pacific Ocean and Hawaii, Geolog. Soc. Am., The Geology of North America N, pp. 21-72.

Stern, R.J. (2002), Subduction zones, Rev. Geophys. 40, 1012, doi:10.129/2001RG000108.

Stock, J.M., and Hodges K.V. (1989), Pre-Pliocene extension around the Gulf of California and the transfer of Baja California to the Pacific plate, Tectonics 8, 99-115.

Sun, S.S., and McDonough, W.F. (1989), Chemical and isotopic systematics of oceanic basalts: Implications for mantle composition and processes, In (Saunders, A.D., and Norry, M.J. Eds.), Magmatism in the ocean basin, Geological Society of London Special Publication 42, pp. 313-345. 
Thorkelson, D.J. (1996), Subduction of diverging plates and the principles of slab window formation, Tectonophysics 255, 47-63.

Thorkelson, D.J., and Breitsprecher, K. (2005), Partial melting of slab window margins: genesis of adakitic and non-adakitic magmas, Lithos 79, 25-41.

Till, C.B., Gans, P.B., Spera, F.J., MacMillan, I., and Blair, K.D. (2009), Perils of petrotectonic modeling: a view from southern Sonora, Mexico, J. Volcan. Geotherm. Res. 186, 160-168.

Turner, S., Evans, P., and Hawkesworth, C. (2001), Ultrafast source-to-surface movement of melt at island arcs from ${ }^{226} \mathrm{Ra}^{230}$ Th systematic, Science 292, 1363-1366.

Turrin, B.D., Gutmann, J.T., and Swisher III, C.C. (2008), A $13 \pm 3$ ka age determination of a tholeiite, Pinacate volcanic field, Mexico, and improved methods for ${ }^{40} \mathrm{Ar} \mathrm{P}^{39} \mathrm{Ar}$ dating of young basaltic rocks, J. Volcanol. Geotherm. Res. 177, 848-856.

Umhoefer, P.J., Dorsey, R.J., Willsey, S., Mayer, L., and Renne, P. (2001), Stratigraphy and geochronology of the Comondu Group near Loreto, Baja California Sur, Mexico, Sedimentary Geology 144, 125-147.

Vidal-Solano, J.R. (2005), Le volcanisme hyperalcalin d'âge miocène moyen du nord-ouest du Mexique (Sonora). Minéralogie, géochimie, cadre géodynamique, Thèse de Doctorat, Université Paulk Cézanne, Aix-Marseille 3 (France), pp. 256.

Vidal-Solano, J.R., Paz Moreno, F.A., Iriondo, A., Demant, A., Cochemé, J.-J. (2005), Middle Miocene peralkaline ignimbrites in the Hermosillo region (Sonora, México). Geodynamic implications, C. R. Geoscience 337, 1421-1430.

Vidal-Solano, J.R., Paz Moreno, F.A., Demant, A., and López-Martínez, M. (2007), Ignimbritas hiperalcalinas del Mioceno medio en Sonora Central: revaluacion de la estratigrafía y significado del volcanismo terciaro, Rev. Mex. Cien. Geológ. 24, 47-67.

Vidal-Solano, J.R., Demant, A., Paz Moreno, F.A., Lapierre, H., Ortega-Rivera, M.A., and Lee, J.K.W. (2008a), Insights into the tectonomagmatic evolution of NW Mexico: geochronology and geochemistry of the Miocene volcanic rocks from the Pinacate area, Sonora, Geolog. Soc. Am. Bull. 120, 691-708.

Vidal-Solano, J.R., Lapierre, H., Stock, J.M., Demant, A., Paz Moreno, F.A., Bosch, D., Brunet, P., and Amortegui, A. (2008b), Isotope geochemistry and petrogenesis of peralkaline Middle Miocene ignimbrites from central Sonora: relationship with continental break-up and the birth of the Gulf of California, Bull. Soc. Géolog. France $179,453-464$. 
Wilson, D.S., McCrory, P.A., and Stanley, R.G. (2005), Implications of volcanism in coastal California for the Neogene deformation history of western North America, Tectonics 24, TC3008, doi:10.129/2003TC001621.

Zellmer, G.F. (2008), Some first-order ob servations on magma transfer from mantle wedge to upper crust at volcanic arcs, Geolog. Soc. London, Special Publications 304, 15-31.

Zellmer, G.F., and Annen, C. (2008), An introduction to magma dynamics, Geolog. Soc. London, Special Publications 304, 1-13.

Zellmer, G.F., Annen, C., Charlier, B.L.A., George, R.M.M., Turner, S.P., and Hawkesworth C.J. (2005), Magma evolution and ascent at volcanic arcs: constraining petrogenetic processes through rates and chronologies, J. Volcan. Geother. Res. 140, 171-191.

\section{Figure captions}

Fig. 1. Geological sketch map of Baja California and Sonora, showing the major Neogene and Quaternary volcanic fields and the distribution of the main lava types. The regional geology is modified from Ortega-Gutiérrez et al. (1992), Calmus et al. (2003, 2008), Pallares et al. (2007) and Consejo de Recursos Minerales (1992).

Fig. 2. Incompatible multi-element patterns of selected lava types from the northwestern Mexican margin normalized to the Primitive Mantle of Sun and McDonough (1989). (a): "Regular" calc-alkaline lavas from Baja California volcanic fields (Martín-Barajas et al., 1995; Aguillón-Robles et al., 2001; Benoit et al., 2002; Pallares et al., 2007, 2008;) and Sonora volcanic fields (Vidal-Solano et al., 2005, 2007, 2008; Till et al., 2009); (b): Adakites from Santa Clara Volcanic Field (Aguillón-Robles et al., 2001) and Jaraguay Volcanic Field (Pallares et al., 2007, 2008); (c): Magnesian basalts, basaltic andesites and andesites from Baja California volcanics fields (Calmus et al., 2003; Bellon et al., 2006; Pallares et al., 2007, 2008); (d): Niobium-enriched basalts from Santa Clara Volcanic Field (Aguillón-Robles et al., 2001); (e): Alkali basalts and trachybasalts from San Quintín Volcanic Field (Luhr et al., 1995), Moctezuma Volcanic Field (Paz-Moreno et al., 2003), San Carlos Volcanic Field (Pallares et al., 2007, 2008), and Pinacate Volcanic Field (Vidal-Solano et al., 2008); (f): Oceanic (MORB-type) basalts from Isla Tortuga (Batiza, 1978) and Guaymas Basin (Saunders et al., 1982b); (g): Tholeiitic and 
transitional basalts and basaltic andesites from San Ignacio-San Juanico Volcanic Field (Benoit et al., 2002), Las Trincheras Volcanic Field (Mora-Klepeis and McDowell, 2004), Moctezuma Volcanic Field (Paz-Moreno et al., 2003), Central Sonora (VidalSolano et al., 2005, 2007, 2008) and Coastal and Eastern Sonora (Till et al., 2009); (h): Peralkaline rhyolites and icelandites from Sonora volcanic fields (Vidal-Solano et al., 2005, 2007, 2008).

Fig. 3. Sketches of Baja California and Sonora at various periods showing the locations and types of lavas together with structural elements of the adjacent Pacific Ocean and the Gulf of California. (a): Early-Middle Miocene (Aquitanian to Langhian): tectonic setting drawn at 16 Ma from Wilson et al. (2005). (b): Middle-Upper Miocene (Serravallian to Messinian): tectonic setting at $11 \mathrm{Ma}$ (Wilson et al., 2005; Pallares et al., 2007; Maury et al., 2009), during the peak of adakitic volcanism in Santa Clara. (c): PlioceneQuaternary: present-day tectonic setting from Calmus et al. (2008). The present-day coastal lines are depicted on this reconstruction, but the Gulf of California did not exist at 16 and 11 Ma. Abbreviated plate names: PAC (Pacific); MAG (Magdalena); GUA (Guadalupe). The distribution of Aquitanian-Langhian, Serravallian-Messinian and PlioQuaternary volcanic rocks is from Batiza (1978); Saunders et al. (1982b); Luhr et al. (1995); Martín-Barajas et al. (1995); Aguillón-Robles et al. (2001); Benoit et al. (2002); Calmus et al. (2003, 2008); Oskin and Stock (2003); Paz-Moreno et al. (2003); MoraKlepeis and McDowell (2004); Conly et al., (2005); Bellon et al. (2006); Pallares (2007); Pallares et al. (2007, 2008); Vidal-Solano et al. (2005, 2007, 2008a,b); Till et al. (2009). Abbreviations for volcanic fields/localities discussed in the text are as follows: CLR (Caldera La Reforma), CP (Cerro Prieto), CSP (Cerro San Pedro), CS (Coastal Sonora), CST (Cerro Starship, Isla Tiburón), EP (El Paraiso), G (Guaymas), GB-S477 (Guaymas Basin DSDP site 477), GB-S478 (Guaymas Basin DSDP site 478), GB-S479 (Guaymas Basin DSDP site 479), GB-S481 (Guaymas Basin DSDP site 481), HI (Hilarenos), ICO (Isla Coronado), ISE (Isla San Esteban), ISL (Isla San Luís), ISM (Isla Santa Margarita), JA (Jaraguay), JA-CA (Jaraguay-Cataviña), JA-EC (Jaraguay-El Crucero), JA-LCH (Jaraguay-Laguna de Chapala), JA-SI (Jaraguay-Santa Inés), LB (Sierra Lista Blanca), LM (Los Mencenares), LP (La Purísima), LP-SC (La Purísima-San José de Comondú), LPU-CLC (La Purísima-Cerro Los Cerritos), LPU-CP-CJM (La Purísima-Cerro Pabellón-Cerro Jesús del Monte), LPU-SM (La Purísima-San Miguel), LT (Las 
Trincheras), M (Moctezuma), MSC (Mesas San Carlos and Santa Catarina), P

(Puertecitos Volcanic Province), PI (Pinacate), S (Sahuaripa), SB (San Borja), SB-RO (San Borja-Rosarito), SB-SI (San Borja-San Ignacito), SC (Santa Clara), SEA (Sierra El Aguaje), SF (San Felipe), SG (Suaqui Grande), SI (San Ignacio), SIG-SF (San IgnacioSan Francisco), SL (Sierra Libre), SM (Sierra de Mazatán), SQ (San Quintin), SR (Santa Rosalía), SRO (Santa Rosa), SSA (Sierra San Antonio), SU (Sierra Santa Ursula), TV (Tres Virgenes), VIZ (Vizcaíno).

Fig. 4. Three schematic W-E cross sections from the paleo-trench to Sierra Madre Occidental, showing relationship between the evolution of volcanism and tectonics from $12 \mathrm{Ma}$ to present, at ca. $28^{\circ} \mathrm{N}$ latitud. A: Between ca. 12 and $9 \mathrm{Ma}$, the activity of Magdalena ridge decreased and the right-handed motion between Pacific and North America plates began along the Tosco-Abreojos fault zone. The localization of the Oligocene to Early Miocene metamorphic core complex (MCC) belt and schematic Basin and Range faulted structure are shown. Note that there is no Basin and Range structure in Baja California. B: The plate motion is partitioned into the waning Tosco-Abreojos fault zone and the Gulf of California, here the Tiburón transform fault (TTF). The Gulf Extensional Province is located along the western Basin and Range Province. C: At present time, the dextral transform motion is principally controlled by faults within the Gulf, here the Ballena transform fault (BTF). Note the intracontinental Quaternary basaltic volcanism in the Moctezuma region. For A, B and C, see text for the source and origin of volcanism. SBTAFZ (San Benito Tosco Abreojos Fault Zone), MCC (metamorphic core complex), MGE (Mean Gulf Escarpment), TTF (Tiburón transform fault), BTF (Ballena transform fault). 


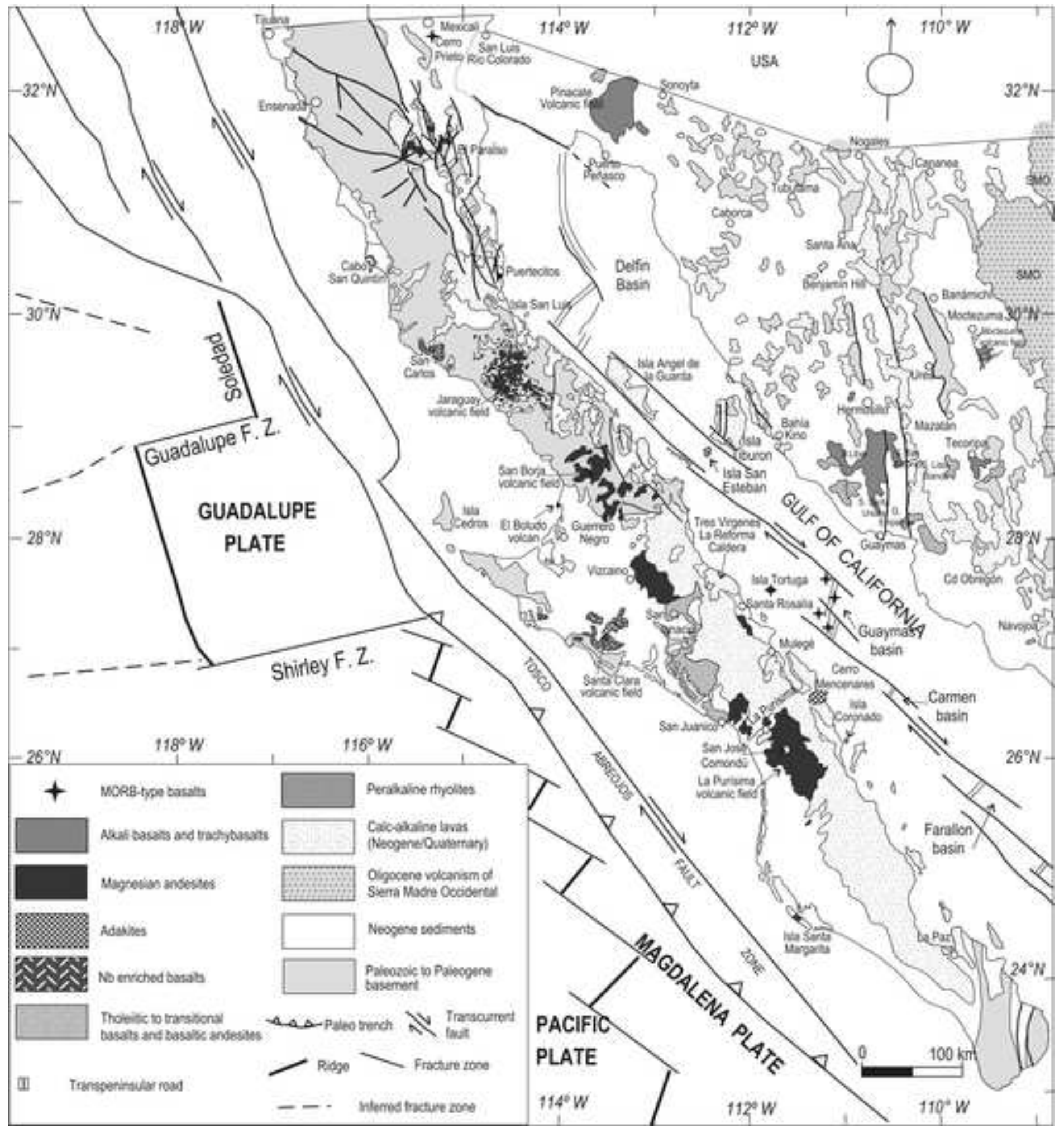



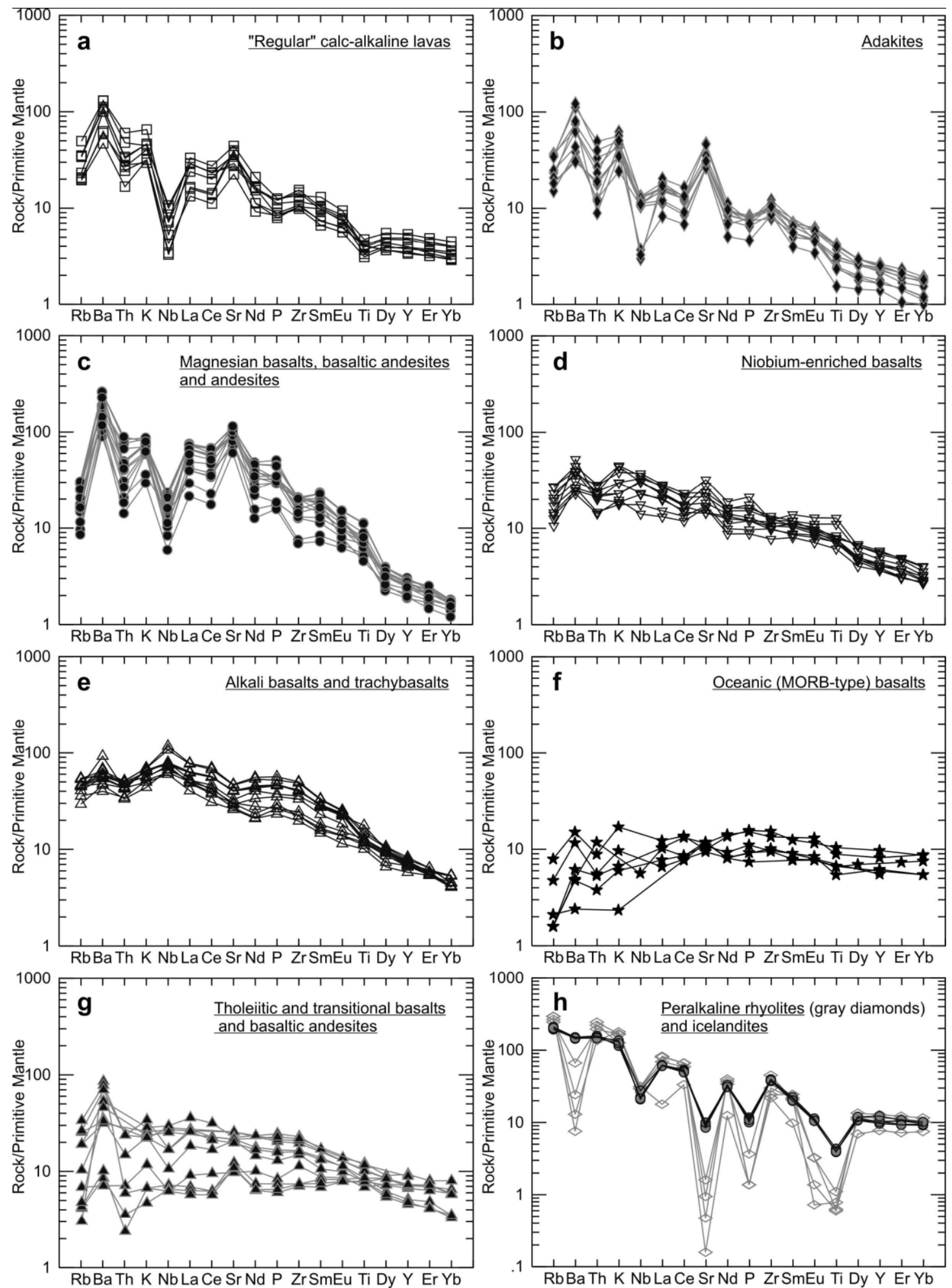


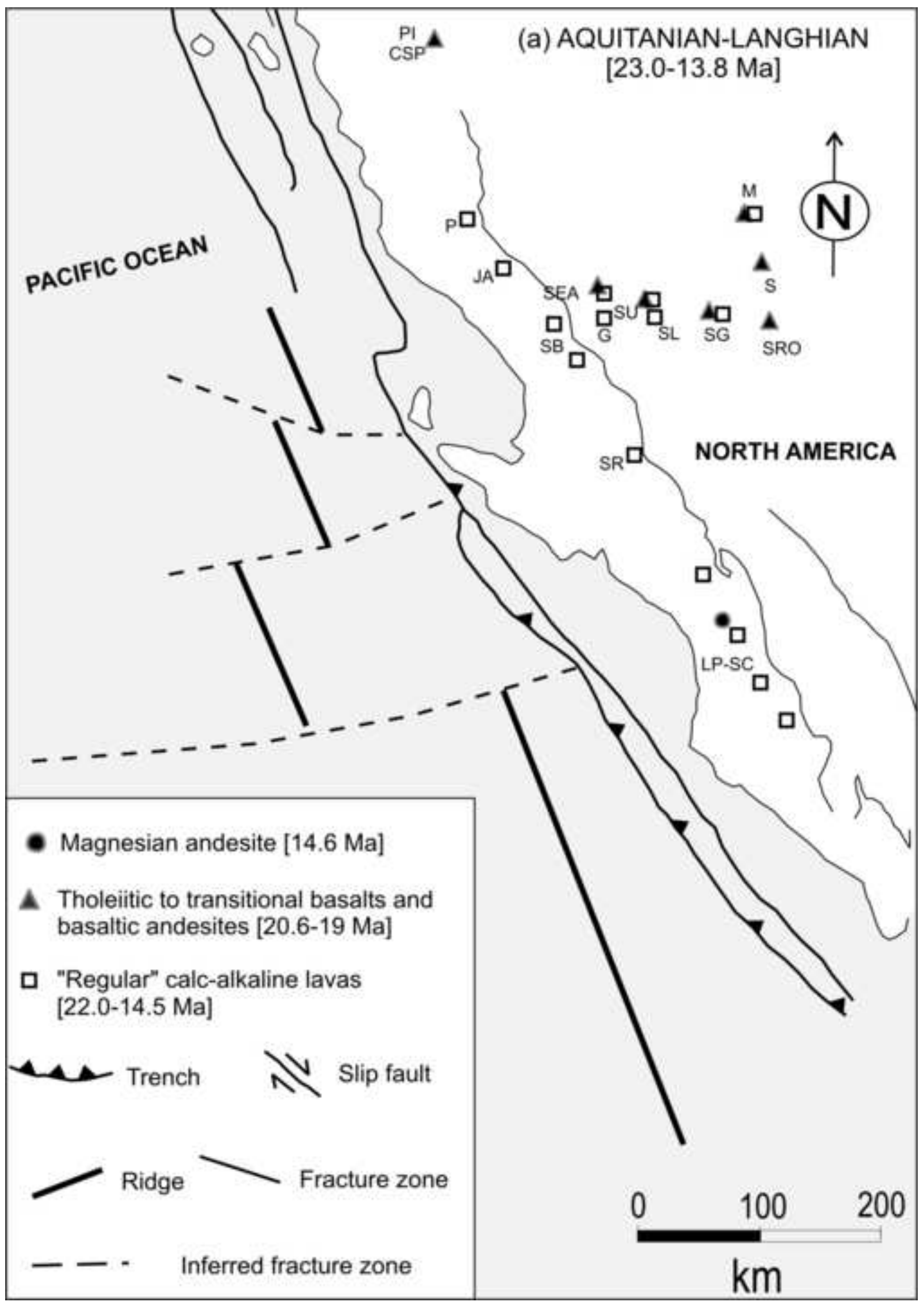




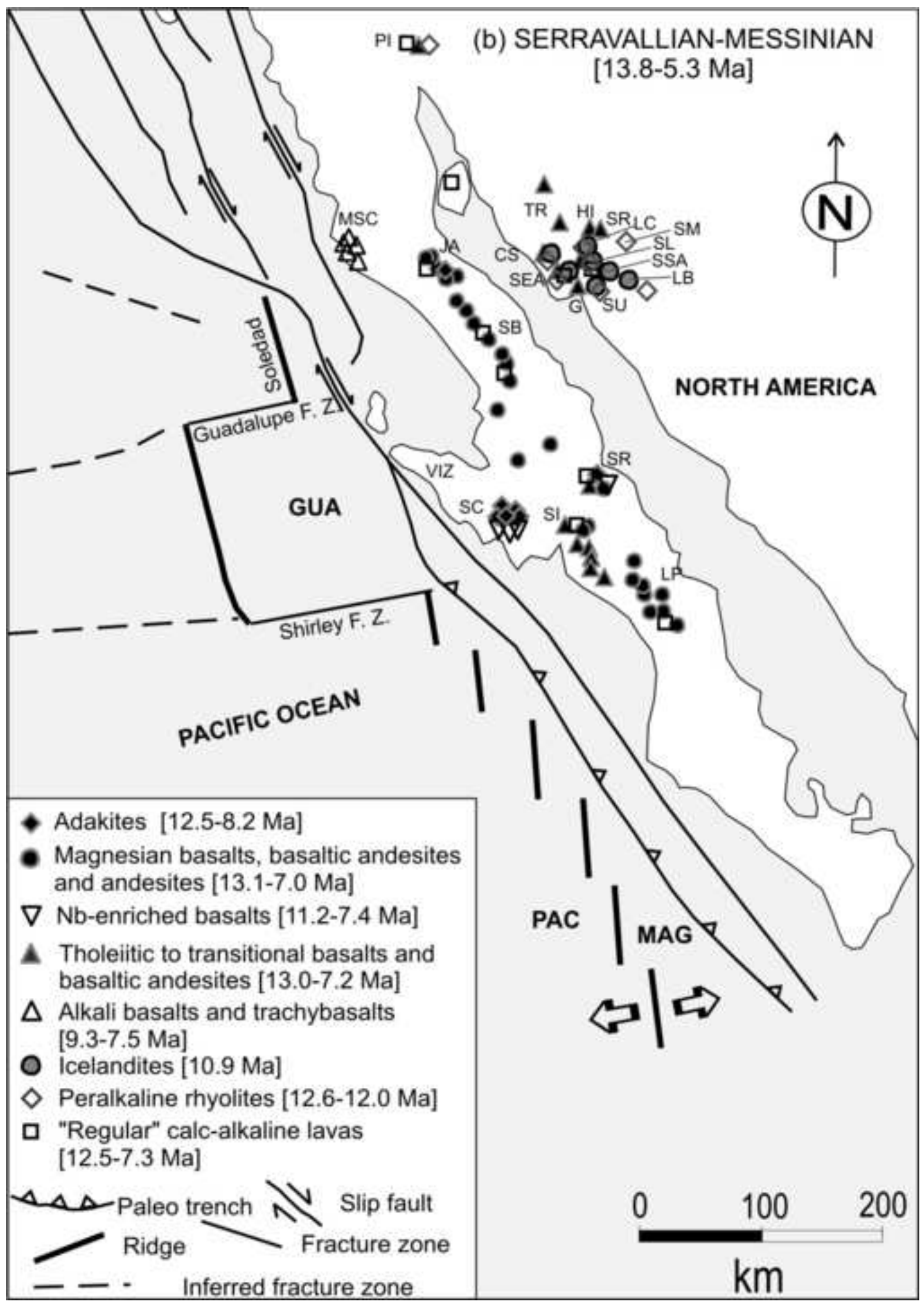




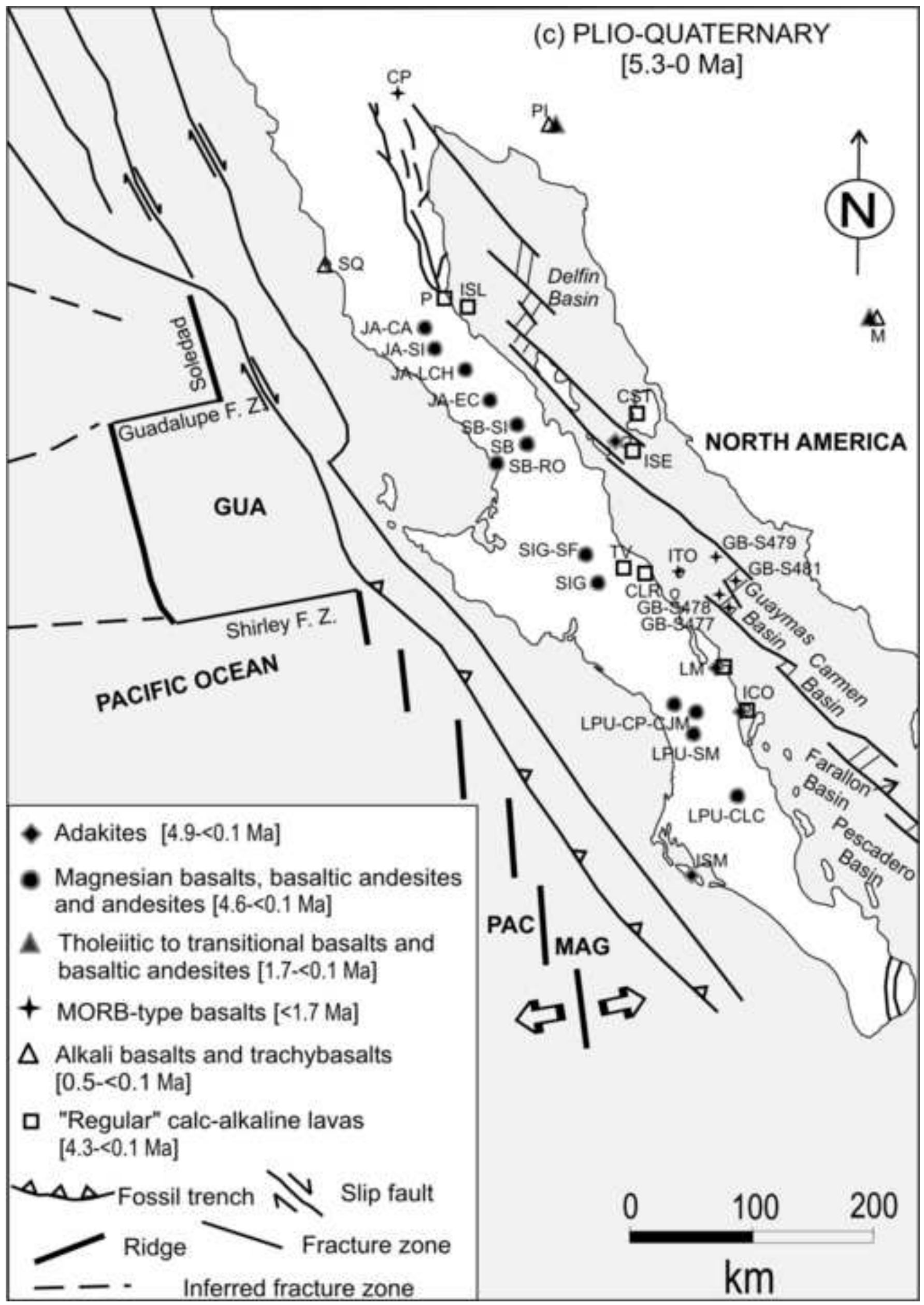




\section{Figure}

Click here to download high resolution image
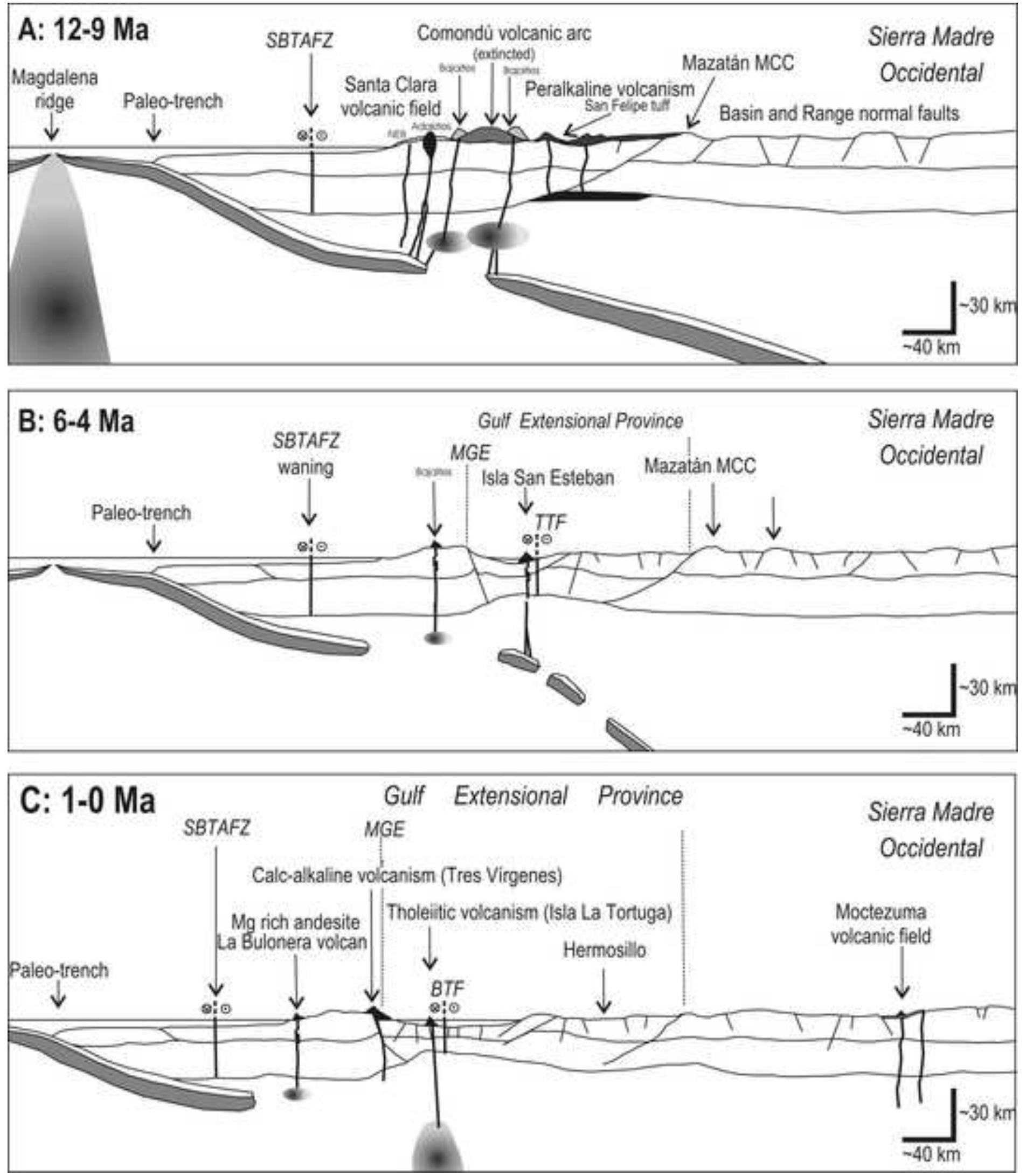